\title{
Omics Application in Animal Science-A Special Emphasis on Stress Response and Damaging Behaviour in Pigs
}

\author{
Claudia Kasper ${ }^{1, *(\mathbb{C}}$, David Ribeiro ${ }^{2}\left(\mathbb{D}\right.$, André M. de Almeida $^{2}$, Catherine Larzul ${ }^{3}{ }^{(D)}$, \\ Laurence Liaubet $^{3(D)}$ and Eduard Murani ${ }^{4, *}$ (D) \\ 1 Swine Research Unit, Agroscope, La Tioleyre 4, 1725 Posieux, Switzerland \\ 2 Departamento de Ciências e Engenharia de Biosistemas, Instituto Superior d'Agronomia, Universidade de \\ Lisboa, Tapada da Ajuda, 1349-017 Lisboa, Portugal; davidribeiro@isa.ulisboa.pt (D.R.); \\ aalmeida@isa.ulisboa.pt (A.M.d.A.) \\ 3 Génétique Physiologie et Systèmes d'Elevage (GenPhySE), INRA, 24 chemin de Borde-Rouge-Auzeville \\ Tolosane, 31326 Castanet Tolosan, France; catherine.larzul@inrae.fr (C.L.); laurence.liaubet@inrae.fr (L.L.) \\ 4 Leibniz Institute for Farm Animal Biology (FBN), Institute of Genome Biology, Genomics Unit, \\ Wilhelm-Stahl-Allee 2, 18196 Dummerstorf, Germany \\ * Correspondence: claudia.kasper@agroscope.admin.ch (C.K.); murani@fbn-dummerstorf.de (E.M.) ; \\ Tel.: +41-584687-046 (C.K.)
}

Received: 22 July 2020; Accepted: 7 August 2020; Published: 11 August 2020

\begin{abstract}
Increasing stress resilience of livestock is important for ethical and profitable meat and dairy production. Susceptibility to stress can entail damaging behaviours, a common problem in pig production. Breeding animals with increased stress resilience is difficult for various reasons. First, studies on neuroendocrine and behavioural stress responses in farm animals are scarce, as it is difficult to record adequate phenotypes under field conditions. Second, damaging behaviours and stress susceptibility are complex traits, and their biology is not yet well understood. Dissecting complex traits into biologically better defined, heritable and easily measurable proxy traits and developing biomarkers will facilitate recording these traits in large numbers. High-throughput molecular technologies ("omics") study the entirety of molecules and their interactions in a single analysis step. They can help to decipher the contributions of different physiological systems and identify candidate molecules that are representative of different physiological pathways. Here, we provide a general overview of different omics approaches and we give examples of how these techniques could be applied to discover biomarkers. We discuss the genetic dissection of the stress response by different omics techniques and we provide examples and outline potential applications of omics tools to understand and prevent outbreaks of damaging behaviours.
\end{abstract}

Keywords: genomics; epigenomics; transcriptomics; proteomics; metabolomics; biomarkers; swine; animal welfare; damaging behaviour

\section{Introduction}

Increasing robustness, resilience and efficiency of livestock are pivotal topics in animal science because of their importance to profitable meat and dairy production, but also for ethical, animal welfare and sustainability reasons [1,2]. In this review, we investigate and discuss potential benefits of omics technologies for optimizing stress resilience and reducing damaging behaviour in livestock, in particular pigs. Resilience, i.e., the capacity to quickly return to normal functioning after disturbance [3], depends on intrinsic adaptation mechanisms at diverse functional levels, including the genetic and epigenetic make-up, and on their interaction with extrinsic, environmental factors. A better understanding of those 
factors and how they interact will help to explain individual variation $[4,5]$. Recent efforts to improve performance of livestock species through intensified selective breeding, including increasing lean meat content, growth and feed efficiency, have been associated with a negative impact on homeostasis through correlated responses to selection [4,6,7]. As a result, disease tolerance [8] and resilience to stressors [9] can be compromised. This may ultimately lead to severe welfare problems, such as behavioural disturbances including tail biting in pigs. It is generally understood that tail biting occurs when the adaptation capacity of an animal is overwhelmed by accumulating risk factors, such as lack of manipulable material and poor health or challenging climate [10]. Because of the multifactorial background it is difficult to identify the critical trigger and predict tail-biting outbreaks [11]. Therefore, it is of paramount importance to identify animal-based indicators of vulnerable state in order to prevent tail biting outbreaks. It is equally important to understand in more detail the biology and genetic architecture of damaging behaviour, and more broadly of resilience-related traits, to be able to predict which animals are more vulnerable to stress and, therefore, at greater risk of developing damaging behaviour [12]. Besides its negative impact on animal welfare, damaging behaviour also has a negative impact on economic and environmental sustainability of animal production. Genetic improvement of resilience and breeding of animals less prone to damaging behaviour promises a more sustainable solution compared with management changes $[1,13,14]$, particularly when looking at the limited success of management interventions to mitigate the problem of tail biting $[15,16]$. However, due to the episodic nature and dynamics of tail biting, it is difficult to collect direct records of use for breeding [13]. Especially tail-biters are difficult to identify, whereas victims are easily discernible by their wounds. An enormous amount of time for live observations or video analysis is needed, which hinders routine high-throughput phenotyping. Similarly, resilience is not directly measurable, but a concept that requires measuring experienced stress via proxies or biomarkers over time. The development of generally accepted and reliable biomarkers is not yet so advanced that this could be a common strategy. Therefore, breeding would be facilitated by dissecting these complex traits into biologically better defined, heritable and easily measurable proxy traits. This goal calls for the application of holistic omics approaches (hereafter referred to as "omics"), which are high-throughput molecular technologies that study the entirety of molecules and their interactions on various levels of biological organization. They go from the level of the DNA (genomics), to its accessibility for transcription (epigenomics), the abundance of gene transcripts (transcriptomics), proteins (proteomics) and metabolites (metabolomics), or characterizing microbial communities, for instance in the gut (metagenomics), in a single analysis step (Figure 1). Omics are able to enlighten the causal biology from the genome via intermediate molecular traits to a complex, external phenotype, but also provide means for high throughput, deep phenotyping. Such fine-grained information offers further the chance to attempt decoupling correlated traits in breeding programs and avoid antagonistic relationship between welfare and performance [12]. In this review, we elaborate on general characteristics and benefits of different omics approaches (Section 2), provide examples of omics application for discovery of biomarkers of stress exposure and vulnerability (Section 3), and for genetic dissection of stress response (Section 4). Finally, we provide examples and outline potential application of omics tools and future directions to understand and prevent tail biting (Sections 5 and 6). In our review, we focus particularly on the stress response as a key biological component of resilience and consequently damaging behaviour. The successful application of omics in exploring the neuroendocrine stress response emphasizes the benefit of dissection of complex traits into biologically well-defined traits. 
STRESS

- Psychosocial (e.g. weaning, mixing, confinement)

- Environmental (e.g. temperature, draft, nutrition)

- Immune (e.g. inflammation response)

xternal environment

ternal environment

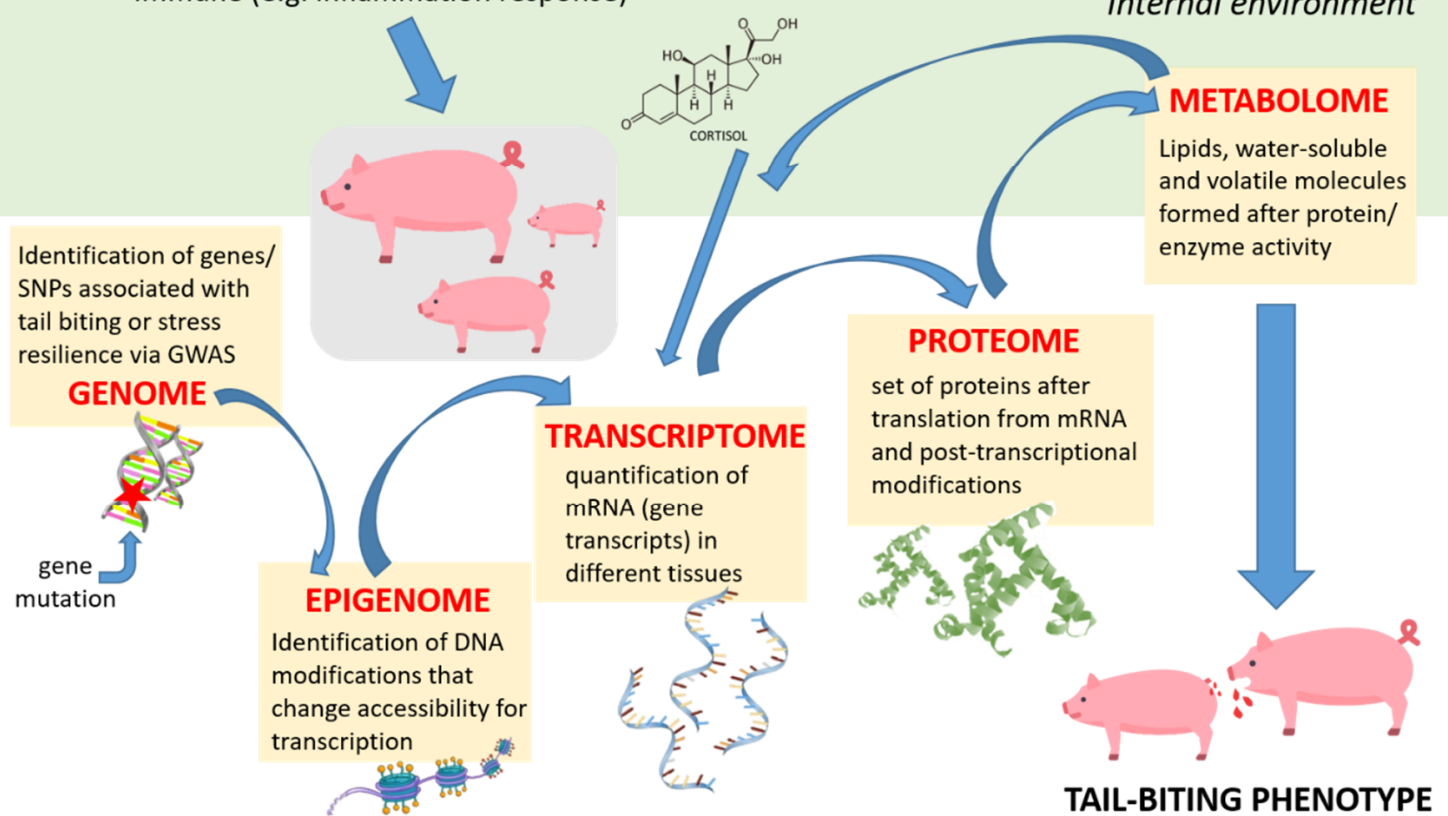

Figure 1. Overview of omics techniques based on a pig model illustrating tail biting. Using genomics, entire genes or single nucleotide polymorphisms (SNPs), which are associated with damaging behaviours or stress susceptibility, can be identified via genotyping or by sequencing the entire genome in a genome-wide association study (GWAS) [17,18]. Transcriptomics allows the quantification of gene expression in relation with the stress response [19]. Proteomics examines the entire set of proteins formed after mRNA translation and subsequent post-translation modifications (PTMs). Particular protein species can be quantified in response to welfare alteration. Metabolomics studies the metabolites (lipids, water soluble and volatile molecules) that are necessary for protein/enzyme activity to occur or are formed because of these reactions [17]. (Figure was created using a pig icon by Freepik from www.flaticon.com).

\section{The Importance of Omics Technologies for Ethical Pig Production}

All omics approaches are fundamentally holistic because they provide information about the set of identified genes present in an individual or characterize the entire microbiome, the entirety of genes transcribed to mRNA or the proteins and metabolites found at a given moment in a particular cell, tissue, organ, fluid, organism or population. Due to their high-throughput nature, these technologies enable the collection of large amounts of data in the form of molecular profiles that provide information about the function of biochemical pathways and thus the functioning of organisms in a certain study. A particularly useful feature of some omics technologies is the ability to characterize and quantify the variation of molecular activity (e.g., transcripts, proteins and metabolites) between individuals, tissues and cells as well as in response to experimental conditions or ecological, behavioural and temporal changes. As some omics technologies can be conducted in a non-destructive and minimally invasive way, they can be used as diagnostic and prognostic tools.

Like most traits of interest in animal science, for instance growth, metabolic and behavioural characteristics, damaging behaviours and stress susceptibility are complex traits. This means that, even though genetic variation underlies trait variation to a certain degree, the genotype-phenotype map is not straightforward. Relevant loci are likely to be high in number and spread across the whole genome, have epistatic relationships with other loci and interact with the environment [20]. The genetic basis 
of the stress response in pigs will be outlined in more detail in Section 4. Differences in the genetic makeup only partly explain why individuals vary regarding the susceptibility to stress, the propensity to perform damaging behaviours or the failure to resist being bitten by a conspecific. The physical and social environment and genotype-environment interactions (GxE) provide major contributions to individual variation in behaviours and coping styles [21,22]. Early experience and exposure to stressors during developmental stages that are particularly sensitive to environmental challenges can result in permanent modifications of chromatin accessibility [23], leaving a distinctive epigenetic signature that could be exploited in future research on farm animals. The immediate state or environment of an individual can also influence the way genes are transcribed by the action of hormones and neurotransmitters, thereby altering their level of expression and the amount of protein translated (Figure 1). Thus, due to its complexity, the study of stress susceptibility or damaging behaviours requires a systems biology approach. This means that information from different omics techniques, such as gene polymorphisms, quantification of gene transcripts and proteins, metabolites or hormones have to be integrated to obtain a more complete picture of the processes that result in the observed phenomenon. Integrating information across levels of biological organization and environmental conditions is expected to facilitate the understanding of how causative genetic polymorphisms give rise to different phenotypes. For instance, one can study how the combination of genetic polymorphisms, chromatin modifications, hormones and/or the immune system ("intermediate phenotypes"), [24] together result in a tail biting or stress susceptible phenotype. A range of methods exist that facilitate the integration of multi-omics data, such as network or pathway analysis, principal component analysis (or other data reduction methods) and deep learning [25-32]. However, as discussing these methods would go far beyond the scope of this review, we provide a cursory overview of software packages that implement multi-omics integration in Table 1. 
Table 1. Overview of some free bioinformatics software for the integration of information across several omics techniques.

\begin{tabular}{|c|c|c|c|c|}
\hline Name & Characteristics & Integration of Types of Omics & Type of Analysis & Reference and URL \\
\hline Cytoscape & standalone software & $\begin{array}{l}\text { Mainly protein-protein, protein-DNA } \\
\text { and DNA-DNA interactions, but } \\
\text { plug-ins (apps) are available for all } \\
\text { types of omics }\end{array}$ & $\begin{array}{l}\text { Provides tools to visualize complex molecular and genetic interaction networks, but } \\
\text { also network analysis, enrichment analysis, ontology analysis and pathway analysis } \\
\text { (e.g., KEGG) is possible. }\end{array}$ & $\begin{array}{c}{[33]} \\
\text { https://cytoscape.org/ }\end{array}$ \\
\hline MOFA & R package (via Bioconductor) & All types (multi-omics) & $\begin{array}{l}\text { Multi-Omics Factor Analysis enables the unsupervised integration of heterogeneous } \\
\text { data sets via a generalization of principal components analysis. MOFA implements } \\
\text { hidden factors of biological and technical sources of variability and represents } \\
\text { integrated data in an interpretable low-dimensional form. }\end{array}$ & $\begin{array}{l}{[34]} \\
\text { https://github.com/bioFAM/MOFA }\end{array}$ \\
\hline LUCID & R package (via CRAN) & $\begin{array}{l}\text { Mainly genomics and metabolomics; } \\
\text { integration of phenotypic data }\end{array}$ & $\begin{array}{l}\text { Uses Latent Unknown Clusters with Integrated Data models to distinguish unique } \\
\text { genomic, exposure and informative biomarkers or omics effects. Latent underlying } \\
\text { relationships with phenotypic traits are estimated in cluster estimations using directed } \\
\text { acyclic graphs (DAG). Prediction of phenotypes possible. Visualization of data } \\
\text { integration with Sankey diagrams. }\end{array}$ & $\begin{array}{l}{[35]} \\
\text { https://github.com/USCbiostats/LUCIDus }\end{array}$ \\
\hline MultiDataSet & $\mathrm{R}$ package (via Bioconductor) & $\begin{array}{l}\text { Epigenomics, transcriptomics; assay } \\
\text { data, feature data, phenotypic data } \\
\text { stored in single object }\end{array}$ & $\begin{array}{l}\text { Does not provide tools for analysis itself, but constructs an } \mathrm{R} \text { data-storage object that } \\
\text { contains multiple data sets, making managing and subsetting multiple and } \\
\text { non-complete data sets possible. This data set can be plugged in to other R packages for } \\
\text { analysis, for instance for multivariate co-inertia analysis (MCIA in omicade4) or } \\
\text { clustering of multiple tables (in iClusterPlus) }\end{array}$ & $\begin{array}{c}{[36]} \\
\text { https://bioconductor.org/packages/release/bioc/ } \\
\text { html/MultiDataSet.html }\end{array}$ \\
\hline Logicome Profiler & standalone Unix software & $\begin{array}{l}\text { Applied to genomics and } \\
\text { metagenomics, but applicable to any } \\
\text { omics data }\end{array}$ & $\begin{array}{l}\text { Detects statistically significant triplet logic relationships from a binary matrix dataset } \\
\text { (indicating connection, for instance co-occurrence, co-expression). Applies Logic } \\
\text { Analysis of Phylogenetic Profiles (LAPP) method, which is based on normalized mutual } \\
\text { information, to phylogenetic profiling data, but also applicable to gene co-expression } \\
\text { and pathway data. }\end{array}$ & $\begin{array}{l}{[37]} \\
\text { https://github.com/fukunagatsu/LogicomeProfiler }\end{array}$ \\
\hline CoCoNet & R package (via Github) & $\begin{array}{l}\text { Integration of GWAS and } \\
\text { gene-expression data }\end{array}$ & $\begin{array}{l}\text { COmposite likelihood-based COvariance regression NETwork model to identify } \\
\text { trait-relevant tissues or cell types. Uses covariance regression network models to } \\
\text { express gene-level effect measurements for a given GWAS trait as a function of the } \\
\text { tissue-specific co-expression adjacency matrix. }\end{array}$ & $\begin{array}{c}\text { [38] } \\
\text { http://www.xzlab.org/software.html }\end{array}$ \\
\hline NEO & $R$ package (via CRAN) & $\begin{array}{l}\text { Integration of GWAS and } \\
\text { gene-expression data }\end{array}$ & $\begin{array}{l}\text { Network Edge Orienting infers directed gene networks by integrating gene-expression } \\
\text { data with genetic marker data and compares them with structural equation models } \\
\text { Weighted Gene Co-expression Network Analysis is used to find clusters relating } \alpha\end{array}$ & $\begin{array}{c}\text { [39] } \\
\text { https://horvath.genetics.ucla.edu/html/aten/NEO/ }\end{array}$ \\
\hline WGCNA & R package (via CRAN) & $\begin{array}{l}\text { Mainly gene-expression data, but can } \\
\text { be applied to other omics }\end{array}$ & $\begin{array}{l}\text { Weighted Gene } \text { Co-expression Network Analysis is used to find clusters, relating } \\
\text { modules to one another and to external sample traits and calculates module membership } \\
\text { measures. This approach facilitates gene screening and the identification of biomarkers. } \\
\text { Multivariate methods to analyse and visualize high-dimensional datasets (number of }\end{array}$ & $\begin{array}{c}\text { [40,41] } \\
\text { https://horvath.genetics.ucla.edu/html/ } \\
\text { CoexpressionNetwork/Rpackages/WGCNA/ }\end{array}$ \\
\hline $\begin{array}{l}\text { DIABLO in } \\
\text { mixOmics }\end{array}$ & R package (via Bioconductor) & All types (multi-omics) & $\begin{array}{l}\text { variables larger than number of samples). Complementary information from several } \\
\text { data sets measured on the same } \mathrm{N} \text { individuals, but across multiple omics data sets is } \\
\text { combined to gain a better understanding of the interplay between the different levels of } \\
\text { data that are measured ('N-integration'). Data dimensions are reduced by applying } \\
\text { sparse generalized canonical correlation analysis (SGCCA). }\end{array}$ & $\begin{array}{c}\text { [42-44] } \\
\text { http://mixomics.org/mixdiablo }\end{array}$ \\
\hline
\end{tabular}




\section{Biomarkers for Stress Resilience in Farm Animals}

Several dimensions define stress: nature, intensity, duration and frequency, as well as predictability and controllability. Pigs are confronted with several types of stressors during their lives [45]. Psychosocial stressors occur when piglets are weaned, mixed with unfamiliar conspecifics or during individual confinement of sows [46]. Environmental stressors include climate, noise, ammonia concentrations, suboptimal nutrition and road transport. Immune challenges during disease or after vaccination represent another type of stressors. Several physiological systems, such as the neuro-endocrine hypothalamic pituitary adrenocortical (HPA) axis, the autonomous nervous sympathetic-adrenal-medullary (SAM) system, and the immune system are implicated in the susceptibility to stress [47], whereby feedback regulation represents a crucial protective mechanisms from excessive action of these systems and consequently biological costs (termed allostatic load; [48]). Omics approaches can help to decipher the contributions of the various systems in terms of their (re)activity and kinetics, and identify candidate molecules that are representative of different physiological pathways. Several biomarkers have been suggested as indicators of various traits important for animal production. Studying the proteome associated with pre-slaughter stress in ruminants yielded a range of candidate proteins that underlie the conversion of muscle to dark, firm and dry muscle [49-52]. Specific findings in pigs, such as on heat stress [53-55], tail docking [56], confined housing [47], physical restraining [57], road transport [58] and inflammatory state [59] have potential to be applied to the stress response in pigs (Figure 2). The main neuroendocrine factors that are currently used as biomarkers describing the acute stress response are cortisol and adrenocorticotropic hormone (ACTH) for the HPA axis, and adrenaline, noradrenaline, and chromogranin A for the SAM system, typically measured in blood or saliva [45]. Long-term activity of the HPA axis or exposure to repeated stress can be revealed by measuring the mass and structure of the adrenal gland [60,61]. Behavioural responses, such as changes in coping style [62] and exploratory [63] and sickness behaviour [46], also reflect the amplitude and duration of the stress response and individual propensity to adapt to stress.

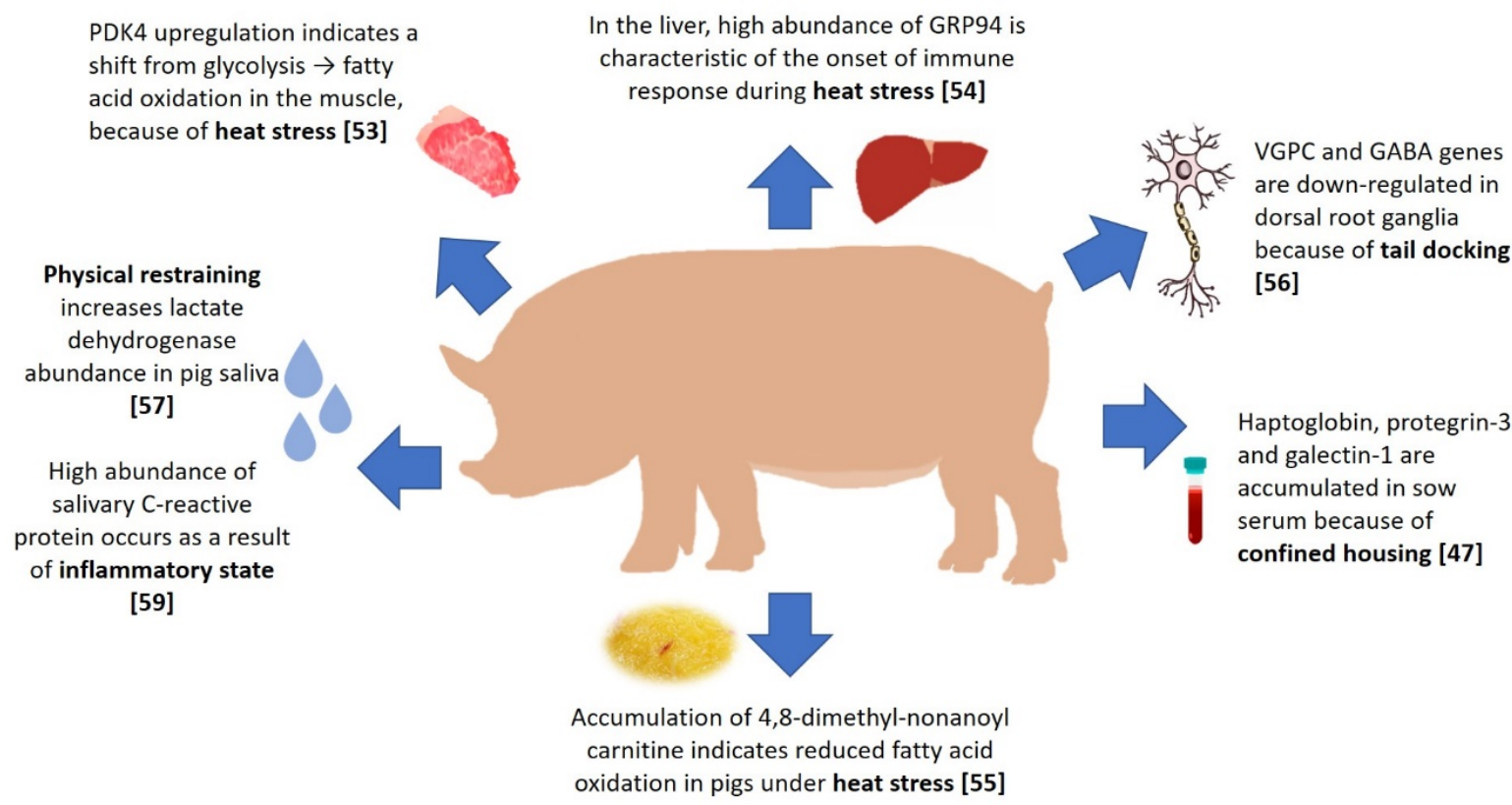

Figure 2. An overview of biomarkers related to welfare issues in pig production. 
Holistic omics approaches promise to yield novel biomarkers for reactivity and vulnerability to stress, but also provide insight into stress biology. The development of biomarkers will enable fast and reliable tests that complement behavioural observations. The choice of which omics technique to use depends on the physiological level one wants to evaluate and towards what purpose. The discovery and development of heritable biomarkers through genomics may inform future genetic studies (see Section 4 for more details) and improve sire/dam selection programmes (see Sections 5 and 6 for more details). Furthermore, genomic biomarkers are particularly well suited for the early prediction of general stress susceptibility or the predisposition to tail biting. However, if the objective is to assess the current or recent exposure to stress, using proteomics and metabolomics to search for associated biomarkers might be a preferable approach. Proteomics and metabolomics both integrate signals from genetic and environmental contributions. By presenting a snapshot of proteins and metabolites, they provide information about the functional state of an individual, which is close to functional endpoints and phenotype [64]. More generally, omics technologies have the potential to provide novel insights into stress biology and its links to production traits, health and welfare. Single biomarker molecules or types of biomarkers (e.g., transcripts, proteins/peptides or metabolites) will not capture the complexity of the stress response very well $[45,64]$, and they are often not specific enough to indicate exposure to stress [47]. The combination of complementary omics techniques is, therefore, well suited to find unique signatures of molecular patterns underlying stress susceptibility. In addition to identifying biomarkers, using complementary omics techniques will increase our general biological understanding of the interplay of diverse physiological systems that are implicated in stress susceptibility and stress response in normal functioning and in a disturbed state. The candidate molecules identified in such studies, which have the potential to allow the diagnostics of specific states, such as the vulnerability to fall victim to tail biting or to engage in this damaging behaviour, can then be further tested and validated as biomarkers.

A good biomarker should be assessed from a sample that is easily obtainable and allows minimally invasive collection, for instance from saliva, urine or faeces, hair or feathers, rather than from blood. Ideally, the same individual can be sampled repeatedly [47]. It is of utmost importance that biomarkers enable objective measurement and evaluation [64] and are specific for a particular state or disease [65]. Thus, biomarker molecules should be sensitive and statistically clearly and consistently associated with a specific normal or pathogenic process $[47,64,65]$ or the risk of an individual to develop a disease [65]. Measurement of biomarker molecules should be simple and cost-effective, and the target molecule should be stable $[47,65]$. Assessment of biomarkers early in life allows early detection and intervention [64] if they are predictive of future outcomes (see Section 6). To validate biomarkers, the application of suitable statistical approaches [65] as well as an established scientific framework and a substantial body of evidence are crucial [64]. Each omics technique provides complementary information and has the potential to identify different potential candidate biomarker molecules (Table 2). Heritable biomarkers of vulnerability and predisposition can be identified using genomics (see Section 4). Environmental challenges may be revealed by epigenetic biomarkers, and include histone modifications or DNA methylation patterns. A landmark in the research and diagnosis of long-term impact of adverse life events has been the discovery of epigenetic programming of stress responsiveness in the offspring by maternal care after birth in rodents [66], changing hippocampal expression [67] and leaving a striking epigenetic signature in and around the glucocorticoid receptor locus [68]. Similar epigenetic signatures have been discovered in humans with a history of childhood abuse [68]. Epigenetic biomarkers have been developed for diagnosis of metabolic diseases and, perhaps of most interest here, neuropsychiatric disorders in humans [69-71]. In pigs, the influence of early-life stress has been extensively studied and documented (reviewed in [72]; however, with few exceptions [73], the epigenome alterations remain largely unexplored. Transcriptomics can be used to associate gene-expression profiles or profiles of non-coding RNA (for instance, long non-coding RNAs, lncRNAs; micro-RNAs, miRNAs; and small interference RNAs, siRNAs) with stress vulnerability or resilience phenotypes $[74,75]$. MiRNAs seem to be especially promising for biomarker development 
because miRNAs circulating in the blood have been shown to reflect resilience or vulnerability to social stress in rats [74]. Salivary miRNAs that reflect a particular condition well have even greater prospects of application in animal welfare due to the reduced invasiveness of saliva compared to blood samples. Following tail-docking without anti-inflammatory treatment, the concentrations of three salivary miRNAs were increased compared with a group that received treatment [76]. Interestingly, the combination of just two miRNA concentrations, miR-19b and miR-365, was sufficient to distinguish treatment groups [76]. This type of molecule harbours potential for translational research since they are highly conserved across species [77]. However, single miRNAs might not be specific to a particular disorder [75]. Proteomics is well suited to screen biofluids, such as blood, urine or saliva, for specific proteins associated with a specific condition or state [65], and in particular, to assess stress in farm animals [47]. The metabolome is informative about the functional state of an organism, and therefore, close to functional endpoints and phenotypes [64]. This aspect and the fact that the metabolites are often not breed- or species-specific [64] suggest a high potential of metabolomics particularly for translational studies. Due to the limited specificity of individual biomarkers, panels of biomarkers may yield better outcomes $[47,64]$. 
Table 2. Putative biomarkers for experienced stress or stress susceptibility in livestock obtained by different omics approaches.

\begin{tabular}{|c|c|c|c|c|c|}
\hline Omics Type & Molecule Type & Molecule Name & Biofluid/Tissue & Description & Reference \\
\hline \multirow[t]{4}{*}{ epigenomics } & DNA methylation & $\begin{array}{l}\text { BCL-2 and RORA } \\
\text { PPIEL }\end{array}$ & $\begin{array}{l}\text { postmortem brains and } \\
\text { peripheral blood cells }\end{array}$ & $\begin{array}{l}\text { hypermethylation of BCL-2 and RORA genes in patients with autism; hypomethylation } \\
\text { of PPIEL in bipolar disorder; hypermethylation of genes involved in brain development } \\
\text { and tryptophan metabolism } \\
\text { peripheral epigenetic biomarkers of schizophrenia; hypermethylation of HTR1A, }\end{array}$ & [78] \\
\hline & DNA methylation & $\begin{array}{l}\text { HTR1A, S-COMT, BDNF1 } \\
\text { HTR1E, COMTD1 and MB-COMT }\end{array}$ & peripheral blood cells & $\begin{array}{c}\text { S-COMT, BDNF 1 } \\
\text { hypomethylation } \\
\text { of HTR1E, COMTD1 and MB-COMT }\end{array}$ & [79] \\
\hline & DNA methylation & VWF and LRRC 32 & hippocampus & $\begin{array}{l}\text { reduced cognition in pigs in response to early life environmental insults (infection with } \\
\text { porcine reproductive and respiratory syndrome virus) is associated with differential } \\
\text { methylation and differential gene expression. VWF and LRRC32 are implicated in blood } \\
\text { brain barrier permeability and regulatory T-cell activation, respectively. }\end{array}$ & [73] \\
\hline & miRNA & $\begin{array}{l}\text { miR-24-2-5p, miR-27a-3p, miR-30e-5p, } \\
\text { mik-3590-3p, } \\
\text { miR-362-3p, and miR-532-5p }\end{array}$ & blood & $\begin{array}{l}\text { pre-challenge circulating miRNAs reflect resilience or vulnerability to } \\
\text { chronic social defeat in rats }\end{array}$ & [74] \\
\hline \multirow{8}{*}{ transcriptomics } & miRNA & mir-132 & diverse tissues and fluids & $\begin{array}{l}\text { associated with post-traumatic stress disorder in humans and animal models in a } \\
\text { systematic review; lack of specificity }\end{array}$ & [75] \\
\hline & miRNA & miR-19b, miR-27b, and miR-365 & saliva & $\begin{array}{l}\text { concentrations greater in pigs that received no anti-inflammatory treatment after tail } \\
\text { docking than in pigs that received treatment }\end{array}$ & [76] \\
\hline & miRNA & range of circulating extra-cellular miRNAs & plasma & $\begin{array}{l}\text { after feed deprivation in chicken lines selected for high and low residual feed intake, } 23 \\
\text { and } 19 \text { miRNAs were found to be differentially expressed between feeding conditions } \\
\text { and lines (indicating influence of genetic background), respectively. }\end{array}$ & [80] \\
\hline & miRNA & range of circulating extra-cellular miRNAs & plasma & $\begin{array}{l}\text { miRNA profiles were different between age classes }(26 \text { miRNAs) and lines ( } 5 \text { miRNAs) in } \\
\text { dairy cattle. Three miRNAs negatively associated with telomere length, but positively } \\
\text { with milk fat yield, mastitis and lameness. }\end{array}$ & [81] \\
\hline & mRNA & profile & dorsal root ganglia & 3000 genes were differentially regulated between docked and undocked pigs & [56] \\
\hline & mRNA & $\begin{array}{l}\text { Pyruvate dehydrogenase (PDK4), heat shock (e.g. } \\
\text { HSPB1) and oxidative (e.g. COX1) genes }\end{array}$ & longissimus dorsi muscle & $\begin{array}{l}\text { up-regulated in the muscle of pigs under heat stress, reflecting the transition from } \\
\text { glycolysis to fatty acid oxidation during chronic exposure to HS }\end{array}$ & [53] \\
\hline & mRNA & profile & liver & $\begin{array}{l}\text { A list of genes dose-dependently regulated by glucocorticoids as biomarkers of stress } \\
\text { action }\end{array}$ & [82] \\
\hline & APP & Pig Major Acute Phase protein & serum & 7-fold increase in pigs after road transport & [58] \\
\hline \multirow[t]{3}{*}{ proteomics } & protein & GRP94 & liver & $\begin{array}{l}\text { of critical importance at the onset of innate immune response, in pigs under HS. induces } \\
\text { an inflammatory response, causing hepatocytes to synthesise haptoglobin (HP) and } \\
\alpha-1 \text {-antichymotrypsin } 2 \text { precursor (SERPINA3) to maintain cell integrity. }\end{array}$ & [54] \\
\hline & protein & lactate dehydrogenase (LDH) & saliva & $\begin{array}{l}\text { significantly increased in the saliva of pigs restrained with a nose snare and in pigs with } \\
\text { lameness. (LDH follows adrenaline production) }\end{array}$ & [57] \\
\hline & protein & $\begin{array}{l}\text { haptoglobin } \\
\text { protegrin-3 and galectin-1 } \\
\beta \text {-actin }\end{array}$ & blood serum & $\begin{array}{l}\text { transition of sows from group to individual confined housing caused increase; indicates } \\
\text { activation of immune defence and cell damage; indicates synthesis of } \\
\text { stress-response hormones }\end{array}$ & [47] \\
\hline metabolomics & metabolite & 4,8-dimetil-nonanoyl carnitine & mesenteric adipose tissue & $\begin{array}{l}\text { accumulation of 4,8-dimetil-nonanoyl carnitine, an intermediary of fatty acid oxidation, } \\
\text { in this tissue of heat stressed pigs }\end{array}$ & [55] \\
\hline
\end{tabular}




\section{Genetics of Stress Response}

\subsection{Quantitative and Molecular Genetics}

Genetic variants are the ultimate biomarkers when it comes to prediction of predisposition or potential to express a specific trait. The genetic material of an individual. i.e. DNA, is available early in development, and is easily obtained from any cellular material available, allowing early prediction of its genetic potential. Currently single nucleotide polymorphisms (SNP) are the genetic variants of choice for genetic studies due to their high abundance (several millions or one SNP per $<1 \mathrm{kbp}$ segregating in a population), stability of the matrix (DNA), mutational stability (i.e. consistency), and categorical nature (most SNPs are biallelic [83]). These features make SNPs perfectly suitable for high throughput interrogation required for genome-wide analyses.

So far, genetic studies of neuroendocrine and behavioural stress responses in farm animals including pigs are scarce due to difficulties to record adequate phenotypes, particularly under practical conditions (see Introduction). Therefore, most genetic studies were carried out under experimental conditions and focused particularly on HPA axis activity, or more specifically on cortisol production and related pathways. The contribution of genetic factors to HPA axis activity is now well established, demonstrated for example, by distinct breed differences. Domestic pigs show less adrenocortical activity than wild boars [84], which is in line with insights gained from domestication experiments in several model species based on selection for tameness [85-88]. Cortisol is a pleiotropic hormone influencing almost all physiological systems including the immune system and energy homeostasis [89]. Therefore, apart from a domestication process based on selection on tameness/docility, differences in HPA axis activity and cortisol production were likely driven further by breeding for greater lean deposition as indicated for example by the observation that breeds showing greater adiposity, e.g., Chinese breeds, typically feature greater cortisol concentrations compared with elite commercial breeds [84,90,91]. However, while cortisol production is linked with a wide range of production traits (i.e., feed efficiency [92], piglet survival [93,94]), this relationship is quite complex and often ambiguous $[95,96]$. This exemplifies the limited explanatory power of individual endocrine biomarkers and hence requirement for a holistic approach integrating other parts of the signalling cascade.

For better understanding of the genetic determinism of HPA axis activity, several studies focused on cortisol concentration, at rest or under challenge. Kadarmideen and Janss [97] estimated a heritability value of 0.40 for basal cortisol concentration measured in urine, but the heritability values reached 0.7 when cortisol concentration was adjusted to creatinine concentration, which allowed for urine dilution by water intake to be taken into account. Larzul et al. [98] estimated a heritability value of 0.19 for basal cortisol concentration in plasma at 6 weeks of age. The cortisol concentration in plasma measured one hour after an injection of ACTH had a heritability value of 0.68 . The genetic correlation between the two measures was 0.94 [98]. Consistent with the considerable heritability, genome-wide linkage or association analyses evidenced several trait-associated loci (QTL) for HPA axis activity or SAM responses (a comprehensive database of QTLs mapped in farm animal species, Animal QTLdb, can be accessed at https://www.animalgenome.org/). Two main QTL regions include the distal end of chromosome 7, harbouring the SERPINA6 locus coding for corticosteroid binding globulin (CBG) [61,99-101] and the distal end of chromosome 2, harboring the NR3C1 locus coding for glucocorticoid receptor (GR) [61,102,103].

Beside HPA axis function, coping strategy also shows a considerable genetic basis. This is typically tested using a so-called backtest [104]. In the test, pigs are placed in a supine position, and latency, duration, and number of struggling bouts is used to classify the coping style [105]. Heritability estimates for performance in the backtest range between 0.10 and 0.50 [105-108]. The main QTL for backtest behaviour was detected on chromosome 12 [109]. Importantly, an association of two peak SNPs in this QTL, particularly rs10720116 (ASGA0055092) located in a prominent functional-positional candidate gene PER1, could be independently validated in a crossbred population. Only few minor QTLs were detected for behavioural stress responses [99], which is consistent with the expected 
highly complex background of such traits. Individual differences in stress responsiveness may also be described indirectly, by exploiting routinely measured traits influenced by stress such as feed intake or growth [110]. Cross et al. [111] analysed the impact of heat stress, measured by temperature humidity index (THI, categorized as normal, alert, danger, emergency), on feed intake in commercial crossbred pigs. Interestingly, breed-associated differences were observed, with Landrace-sired pigs being more heat stress susceptible compared with Duroc or Yorkshire sired pigs. Highest heritability (0.21) showed a change in feeding behaviour between normal and danger THI. QTL on chromosomes 1, 7, 14 and 17 showed the most pronounced effects on changes in feeding pattern due to different THI. Functional annotation of genes in the QTL regions revealed pathways associated with the immune system as overrepresented. The QTL regions contained several heat shock proteins, such as DNAJA4, HPS90AA1 and HSP90AB1, which are obvious candidates due to their role in protecting protein function during heat stress.

Whereas several QTL for different stress-response related traits were mapped, including robust signals such as the QTL for cortisol on SSC7, identification of the causal genetic variants, termed quantitative trait nucleotides (QTN), has proven difficult. So far only one causal QTN has been identified, a missense SNP c.1829C > T (rs335303636) in exon 6 of NR3C1 with major effect on HPA axis activity [61]. The resulting amino acid exchange Ala610Val in the ligand binding domain (LBD) leads to a gain-of-function, enhancing steroid sensitivity of GR presumably by changing the structure of the LBD and strengthening the LBD/ligand interaction [112]. The QTN segregates in diverse commercial pig breeds (German Landrace, German Large White, Pietrain, Duroc) and shows consistent association with cortisol production [61]. Because GR is involved in negative feedback regulation of the HPA axis activity, the enhanced receptor sensitivity (i.e., hypersensitivity) likely leads to compensatory downregulation of the HPA axis early in ontogeny [113]. While the effect on adrenal function is most pronounced, the mutation influences also activity of the central branch of the HPA axis, including corticotropin releasing hormone $(C R H)$ and vasopressin expression [113]. Since these latter neuropeptides are involved also in the regulation of behaviour and SAM, the mutation might have a broader impact on stress responses. In contrast, although SERPINA6 provides a plausible candidate causal locus for the QTL on chromosome 7 [114], the causal genetic variant remains elusive. Nucleotide diversity of SERPINA6 is quite high [115]. Guyonnet-Duperat et al. [116] characterized four amino acid substitutions segregating in the mapping population (Meishan $\times$ Large White). They found that the substitution Gly307Arg, originating from domestic pigs [115], increases CBG capacity and decreases CBG affinity for cortisol. However, the amino acid substitutions do not fully explain the QTL in any of the populations where the QTL has been detected $[114,116,117]$. Apart from coding variation, SERPINA6 function is apparently diversified by regulatory variation [114,117]. Thus, the causal effect might result from an interaction of the regulatory with the coding variation.

It is interesting to note that the main loci, NR3C1 (GR) and SERPINA6 (CBG), affecting the HPA axis in pigs are not those directly involved in the production of HPA axis hormones but rather genes involved in regulation of its activity or signal transduction. This may indicate greater evolutionary or functional constraint on genes involved in production of HPA axis hormones, or vice versa, that variation in regulation might be better tolerated or even beneficial due to reduced pleiotropy and greater flexibility.

\subsection{Functional Genomics}

Many obstacles hamper genetic dissection of complex traits such as stress resilience and damaging behaviour. First, QTL detection requires collection of suitable phenotypes in a large cohort of informative animals, which is, as mentioned in previous sections, difficult for stress resilience and damaging behaviour. Here, omics approaches might provide easily measurable biomarkers, which can be measured in large cohorts with high throughput. Genome-wide association studies are per se hypothesis-free and can be performed for any trait or parameter with reasonable heritability. Another obstacle is the biological and genetic architecture of the trait of interest. Complex phenotypes, as typified 
by the multifactorial damaging behaviour, can be dissected into biologically better-characterized and genetically funded components or intermediate traits by applying omics approaches. This dissection greatly facilitates QTL detection (Figure 3) and may provide the basis for selective breeding. In this regard, different omics levels connecting genotype to phenotype have different degrees of genetic foundation, with the transcriptome having the closest functional connection to the (epi)genome. The most powerful studies are those integrating external and intermediate molecular phenotypes at multiple omics level into a systems genetic or genomic approach $[25,26]$. Furthermore, capturing all genetic variants, including all causal nucleotides, by whole genome sequencing (WGS) will further increase power and precision of QTL mapping [118], but this is methodically challenging. Finally, the most challenging step proved the dissection of the molecular background of identified QTLs. Besides high sequence variation and allelic heterogeneity as in the case of the SERPINA6 locus, another obstacle is linkage disequilibrium, which makes it difficult to distinguish between causal and linked variants. Here, it is essential to complement genetics by functional approaches, including omics. While in most cases, major QTLs are caused by coding variants [119], such as GRAla610Val; it is generally assumed that regulatory variation is the common cause of variation in complex traits $[120,121]$. For a large proportion of genes, their expression is heritable and a considerable part of their variation can be explained by genetics [122]. Genome-wide mapping of expression QTL (eQTL) [123], also referred to as "genetical genomics" [124], has thus become a popular approach to dissect complex trait genetics. Genes whose eQTL are mapped are typically selected based on either positional candidacy and/or correlated expression to variation in the trait of interest. Ponsuksili et al. [103] used this approach to identify genes and networks in skeletal muscle and liver either responding (downstream) to, or influencing (upstream) circulating cortisol in the pigs. First, they identified genes whose expression is significantly correlated to plasma cortisol concentration. Subsequently, they applied GWAS to find eQTL for correlated genes and QTL for plasma cortisol concentration. Finally, the results were integrated using network edge orienting (NEO), a causal modelling algorithm [39]. The study yielded two genes in the muscle and 26 genes in the liver potentially influencing cortisol production, along with 25 and 70 responsive genes, respectively. This study illustrates a suitable approach to resolve causality of relationships between gene expression and manifestation of a trait of interest. Ponsuksili et al. [109] employed eQTL mapping also to resolve the QTL on chromosome 12 for coping behaviour. For this, expression of 37 positional candidates in the hypothalamus was measured. For eight genes, cis-eQTL (i.e., proximal to the gene itself) were mapped. The prospective candidate turned out to be CTC1, featuring overlapping SNPs for the coping behaviour QTL and cis-eQTL. However, the causal variants still await discovery. Beside protein-coding genes, also expression of non-coding RNA is influenced by genetics [125]. However, studies exploring stress-response-related non-coding RNA profiles in a genetic context are scarce (but see $[78,79]$ ).

Pinpointing the causal variant is particularly difficult for regulatory variants, as shown, for example, for the porcine ADRB2 [126,127], a receptor involved in SAM system signalling. Expression of $A D R B 2$ is diversified by several haplotypes depending on tissue context. Furthermore, gene regulation is by far less well understood compared with genetic code and regulatory elements in farm animal genomes are so far poorly annotated. Therefore, the international FAANG (Functional Annotation of Animal Genomes) Consortium was initiated [128]. This uses different functional genomics approaches to generate a high-quality, and high-resolution reference map of functional genome elements in different farm animal species, including pigs. The functional genome annotation will include a comprehensive catalogue of transcribed loci (coding and noncoding), chart of the chromatin landscape (histone modifications, chromatin accessibility and spatial conformation) showing regulatory elements and their interactions, and a chart of the epigenomic landscape represented by DNA-methylation. Such functional genome map will improve our understanding on how environmental factors shape the epigenomic landscape, gene activity and ultimately phenotypic variation, and further greatly facilitate identification of potentially functional, and consequently potentially causal, genetic variants. With increasing number of identified causal variants, knowledge about molecular mechanism of their 
action and genetic mechanisms driving their occurrence and divergence will also accumulate and accelerate identification of further loci. First, sequence based methods for the evaluation of functional consequences and prioritization of genetic variants such as pCADD [129], were developed for farm animals, and it can be expected that these will be further expanded using data generated by FAANG. Furthermore, first methods incorporating functional genome information into genetic studies and genomic prediction are emerging [130,131].

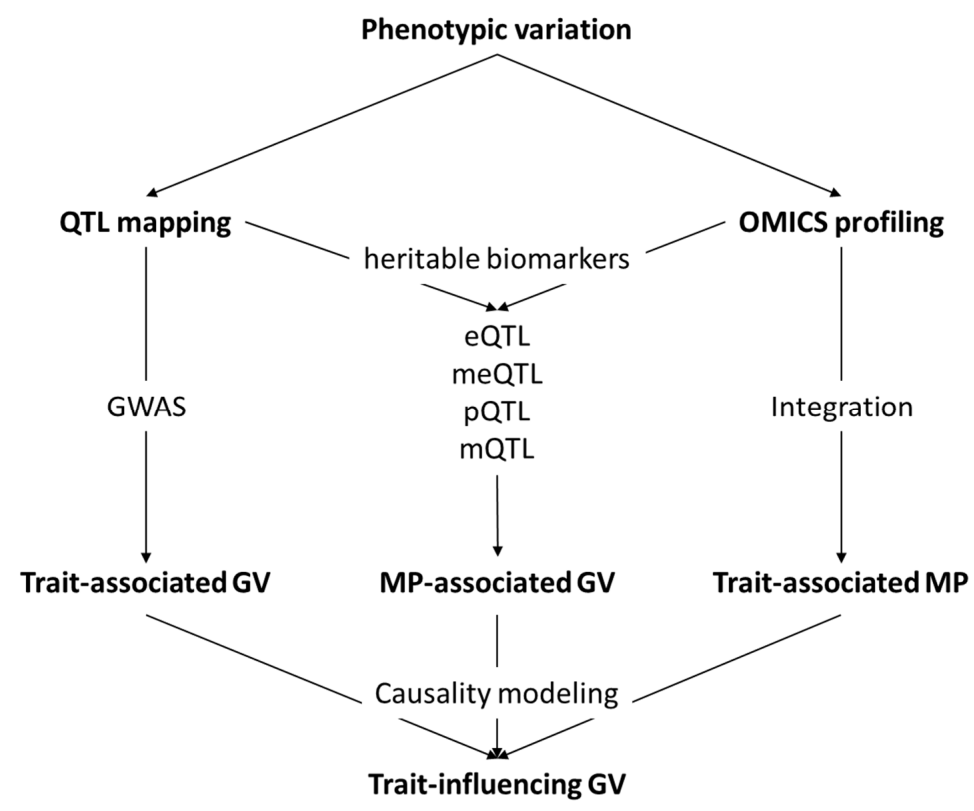

Figure 3. General outline of the integration of omics and genetic analyses in the dissection of the genetic background of complex traits. GV: genetic variation, MP: molecular pattern, QTL: quantitative trait locus, GWAS: genome-wide association study, eQTL: QTL for gene expression, meQTL: QTL for DNA-methylation, pQTL: QTL for protein expression, mQTL: QTL for metabolite, WGCNA: weighted gene co-expression network analysis.

An alternative approach to eQTL mapping for the identification of regulatory polymorphisms is analysis of allele-specific expression or allelic expression imbalance [132]. However, in the context of stress and behaviour-related genes, this sensitive approach has, so far, only been applied to individual candidates in pigs, such as ADRB2 mentioned above [126]. Maroilley et al. [133] applied this approach in combination with eQTL mapping to analyse the genetic architecture of variation in gene expression in the blood (peripheral blood mononuclear cell, PBMC) in pigs. Eleven percent of genes expressed in PBMC showed evidence for allelic expression imbalance, i.e., for cis-regulatory variation, indicating considerable contribution of genetics to gene expression variation as also reported, for example, for mice [134].

\section{Omics to Study Tail Biting}

Tail biting is a damaging behaviour regularly observed in group-housed pigs [135] and it is the source of considerable health problems in pig breeding. Tail docking a few days after birth is currently the main procedure to prevent tail biting, but since 1994, routine tail docking has been forbidden in many European countries by the European legislation for welfare reasons [136]. Genes involved in neuropathic and inflammatory pain pathways were shown to be differentially expressed between tail-docked and sham-treated pigs until 16 weeks after amputation [56], indicating a long-term disturbance of well-being. Tail biting is a multifactorial problem and its occurrence is, therefore, difficult to predict. It is considered as a consequence of living in a stimulus-deprived environment in combination with the high density of animals per pen. Tail biting reflects the primary need to 
forage and explore the environment. Nevertheless, it is considered a sign of stress related to many risk factors, such as the absence of enrichment, comfort (temperature, humidity, air quality, and light) and cleanliness, good health (for instance, gastrointestinal comfort), competition for food, sufficient quality and quantity of food and water, age and genetic predisposition [137]. Genetic differences are evident in that breeds differ in their tendency to become victims of tail biting, e.g., Yorkshire pigs are bitten more often than Landrace pigs [138], and to bite objects (oral rope manipulation) and conspecifics (the latter is shown more often by Duroc pigs than by Large White and Landrace pigs [139]). However, tail biting has a low heritability around 5\% [7]. When the genotypes of pen mates are included in the analysis (indirect genetic effects), heritability can increase up to $24 \%$ (L. van der Zande, unpublished). Indirect genetic effects can contribute to the heritable variation of a trait, and therefore, increase heritability. Moreover, selection for leaner meat and carcasses is genetically correlated with tail biting [7,135,140]. Careful evaluation of the effects of breeding programs and selection experiments on the propensity for tail biting is, therefore, of vital importance. However, tail-biting behaviour is relatively difficult to examine, e.g., injuries to the carcass were frequently observed, which allows the identification of the victims but not the biter [141]. Tail biting is a relevant trait for pig breeders because it impairs animal welfare and causes economic losses to the farmer. Its low heritability in combination with difficulties in obtaining reliable phenotypes and its complex genetic architecture, including also indirect genetic effects (i.e., gene-gene interactions in different individuals) make it particularly difficult to include it in a breeding program. Omics approaches are not yet widely used in breeding nuclei due to the methodological challenges they pose to be routinely implemented in field conditions. Sample collection and phenotyping have to be streamlined to allow integration of collection into routine procedures. The development of easy-to-use and robust collection methods is necessary to guarantee stable outcomes under conditions that are not fully controllable.

Owing to these difficulties, only a few studies using omics technologies have been published to date on tail biting behaviour. Genetic association studies have identified a QTL for the number of lesions in Yorkshire pigs after mixing on chromosome 11 [142]. Being a victim of tail biting was associated with genomic regions on chromosomes 1, 9, 18 and an unassigned region [143]. One association with being a tail-biter could not be assigned to a genomic region and another one was found on chromosome 16 [143]. Thus, it seems that the two traits (being a victim and being a tail-biter) are not genetically linked. The combination of the low availability of genetic loci studies for tail-biting behaviour, the difficulty of distinguishing the initial biter in a group of pigs and the fact that relatively few QTLs and no biomarkers are known, calls for more holistic studies to better understand the architecture of this undesirable trait. In addition to genetics, information on different levels of post-genomic regulation needs to be explored, which can be obtained through transcriptomic, proteomic, metabolomics and even metagenomics studies. While there are few genetic studies of damaging behaviour in pigs or chickens, research on neuropsychological disorders in humans could provide a way forward. A gene expression study in blood allowed the identification of a set of six genes necessary to discriminate obsessive-compulsive disorder from other psychiatric disorders (schizophrenia or depression) and from controls with an accuracy of $86 \%$ [144]. In order to gain power to identify candidate genes, GWAS and transcriptomic data obtained in humans and mice have been combined to study aggressive behaviour [145]. Significantly enriched biological pathways across species were supplemented with phenotypic information to define a ranked list of genes involved [145]. RBFOX1 (RNA Binding Fox-1 Homolog 1), one of the top genes in the lists of significantly enriched signalling pathways in different species, is a regulator of neuronal development [146]. This gene was found to be associated with aggressive behaviour in Drosophila, mice and dogs and in depression, the measurement of well-being, cognitive functions and conduct disorder in humans (reviewed in [147]). Fernàndez-Castillo et al (2020) [147] confirmed the added value of using data from different omics together with other phenotypic studies (e.g., imaging, transgenic mice), even if from different species, to propose more reliable biomarkers and candidate genes. 
Gene expression studies in the brains of victims, performers and "neutral" pigs help shed light on the genes and physiological pathways that have a role in tail biting. Brunberg and colleagues described the transcriptomic analyses of brain structures (hypothalamus and prefrontral cortex) post-mortem from pigs classified as tail biters, victims or neutral pigs [141,148,149], and whether they were able to resist tail biting [148]. More genes were differentially expressed between neutral pigs vs biters and victims than between biters and victims in the hypothalamus and in the prefrontal cortex [149]. Identifying neutral behaviour, and in particular, resistance to damaging behaviour could thus be an interesting starting point for further genetic studies. Some of the genes found differentially expressed were related to production traits in pigs (for instance, PDK4-pyruvate dehydrogenase kinase, isozyme 4; [150] or related to hypersociability in mice (e.g., GTF2I-general transcription factor II-I gene; [151]) The PDK4 gene has also been identified as a possible biomarker of heat stress [152]. Another important gene, EGF (epidermal growth factor), was more highly expressed in biters/victims than in neutral pigs [149]. A polymorphism in this gene has been implicated in novelty seeking [153] in a Finnish human population. Two other genes with potential implications for production traits in pigs were over-expressed in neutral pigs [148], the GHRL gene coding for ghrelin, which is a hormone regulating eating behaviour, and the COMP (Cartilage Oligomeric Matrix Protein) gene [149]. The latter was previously identified as being involved in feather pecking in hens [154]. The functions of the identified genes all correspond to production traits (growth, feed intake, leaner carcass) and to behavioural traits. This is coherent with the idea suggesting that genetic selection for production traits may have also selected damaging behaviour as an undesirable side effect.

The dopaminergic and the serotonergic systems might be highly relevant for the development of biomarkers for tail biting in pigs. The serotoninergic system [155] is involved in many physiological functions as temperature, appetite, sleep, pain, motricity and in cognition (emotion, memory, attention, decision making). The dopaminergic system has an important role in the reward system, influences exploration behaviour and emotional reactions such as fear and anxiety. It is important for coping with stressful environmental conditions and frustrations [156,157]. In pigs, a link has been observed between stress or fear and the serotoninergic system. Tail biters and victims were found to differ in their whole blood and blood platelet concentrations of serotonin (5-HT) from non-tail biters or non-victims [158]. While both tail biters and victims have less whole blood and blood platelet 5-HT than non-biters and non-victims, only biters also had a greater blood platelet uptake velocity [158]. The assessment of peripheral serotonin concentrations may therefore not be informative enough. Peripheral blood serotonin was decreased in biters in comparison to victims [158], similar to what was observed in humans with mental disorders and in laying hens performing feather pecking. Greater concentrations of serotonin were observed in the prefrontal brain of tail-biters compared with victims [159]. Serotonin is involved in the expression of feather pecking behaviour in laying hens, a similar behaviour to tail biting, (reviewed by [160]). Hen lines with high feather pecking tendency have a decreased serotonin content in the brain at young ages, but greater content as adults [160]. The dopaminergic system appears to have a role in feather pecking in hens, since the administration of an antagonist of the dopaminergic system, haloperidol, reduced the occurrence of this damaging behaviour [161]. Feather pecking has been associated with two neighbouring genes involved in dopamine and serotine pathways, one coding for the dopamine D4 receptor (DRD4) and one for the deformed epidermal autoregulatory factor 1 (DEAF1), a repressor of the serotonin receptor transcription [162]. Serotonin and dopamine link damaging and feeding behaviours [160] when nutritional context is also considered as a risk factor to express damaging behaviour. Palander et al [163] have shown that in pigs, victims of tail biting had less plasmatic non-essential amino acids and inorganic phosphate than biters. Those reduced concentrations of nutrients could be related to a reduced ability of intestinal absorption, as indicated by a comparison of the histology of jejunal villi in pens with tail biting compared with pens without damaging behaviour [154]. Nutritional deficiency, compromised gastrointestinal health and associated discomfort, could lead to changes in the gut-brain axis (perhaps including also microbiota) 
and consequently, to unfavourable behaviour [135,141], pointing to a new and exciting target for omics studies.

Taken together, these studies propose that, despite the difficulties of studying damaging behavioural traits, promising strategies for elucidating this complexity have been suggested and could be applied in pigs. The combination of functional and genome-wide association studies could make it possible to better characterize the trait of interest, identify genes and even polymorphisms that could be used in genetic selection. Ideally, the combination is realized within the same study. However, experimental difficulties could be overcome by using available functional (omics) information coming from different projects or even from other species (reviewed in [145]).

\section{Conclusions}

Even though omics technologies are already widely used in animal science, for instance to assess production traits and meat quality, they have not yet been fully exploited for ethical pig production. Tail biting is a complex trait with substantial contribution from the environment and a complicated genetic architecture (potentially including indirect genetic effects). A genetic contribution to the tail-biting phenotype has been demonstrated, but few studies have found regions associated with the stress response in pigs, often without identifying causal variants. The involvement of variation in regulatory regions is expected, which is best captured with a combination of different omics methods. In particular, the integration of several data sets measured on the same individuals and obtained with different omics platforms promises to unravel the interaction between different levels of biological organization. Omics approaches have potential to aid with the development of biomarkers that can be used as diagnostics and prognostic tools of damaging behaviours. Such biomarkers can be useful beyond damaging behaviours and beyond the species level, and might be used as general proxies of welfare in different contexts and for genetic selection of stress-resilient pigs. To achieve this goal, the development of automated, low-input but high-throughput phenotyping strategies that can be easily implemented under field conditions is necessary. Equally important is an improved understanding of the biology of the stress response and the molecular pathways that are implicated in the stress response in different growth stages and environments. Phenomena such as tail biting could be thus dissected into biologically simpler intermediate traits, which have a clearer genetic basis. Ongoing large-scale efforts for improved and more meaningful gene annotation of farm animals will certainly help. Apart from the development of biomarkers, which is a long-term effort, methodological improvements in phenotyping and data integration will facilitate the adoption of omics techniques to study tail biting at the nucleus farm level in the near future.

Author Contributions: Conceptualization, C.K., A.M.d.A., L.L. and E.M.; writing-original draft preparation, C.K., D.R., A.M.d.A., C.L., L.L. and E.M.; writing-review and editing, C.K., A.M.d.A., L.L. and E.M.; visualization, C.K., D.R. and E.M.; project administration, C.K. and L.L. All authors have read and agreed to the published version of the manuscript.

Funding: This research was funded by COST action CA15134 (GroupHouseNet), a PhD grant (SFRH/BD/ 143992/2019) from Fundação para a Ciência e a Tecnologia (Lisbon, Portugal) to D.R. and infrastructural funding LEAF (UID/AGR/04129) from the Fundação para a Ciência e a Tecnologia (Lisbon, Portugal) to A.M.d.A.

Acknowledgments: We thank Lisette van der Zande from Topigs Norsvin and Patrick Stratz and Andreas Hofer from Suisag and Marie-José Mercat from IFIP/Alliance R\&D for input and discussions from the breeders' perspective.

Conflicts of Interest: The authors declare no conflict of interest.

\section{References}

1. Merks, J.W.M.; Mathur, P.K.; Knol, E.F. New phenotypes for new breeding goals in pigs. Animal 2012, 6, 535-543. [CrossRef] [PubMed]

2. Friggens, N.C.; Blanc, F.; Berry, D.P.; Puillet, L. Review: Deciphering animal robustness. A synthesis to facilitate its use in livestock breeding and management. Animal 2017, 11, 2237-2251. [CrossRef] [PubMed] 
3. Scheffer, M.; Bolhuis, J.E.; Borsboom, D.; Buchman, T.G.; Gijzel, S.M.W.; Goulson, D.; Kammenga, J.E.; Kemp, B.; van de Leemput, I.A.; Levin, S.; et al. Quantifying resilience of humans and other animals. Proc. Natl. Acad. Sci. USA 2018, 115, 11883-11890. [CrossRef] [PubMed]

4. Mormede, P.; Terenina, E. Molecular genetics of the adrenocortical axis and breeding for robustness. Domest. Anim. Endocrinol. 2012, 43, 116-131. [CrossRef]

5. Wolf, C.; Linden, D.E.J. Biological pathways to adaptability-Interactions between genome, epigenome, nervous system and environment for adaptive behavior. Genes Brain Behav. 2012, 11, 3-28. [CrossRef]

6. Rauw, W.M.; Kanis, E.; Noordhuizen-Stassen, E.N.; Grommers, F.J. Undesirable side effects of selection for high production efficiency in farm animals: A review. Livest. Prod. Sci. 1998, 56, 15-33. [CrossRef]

7. Breuer, K.; Sutcliffe, M.E.M.; Mercer, J.T.; Rance, K.A.; O'Connell, N.E.; Sneddon, I.A.; Edwards, S.A. Heritability of clinical tail-biting and its relation to performance traits. Livest. Prod. Sci. 2005, 93, 87-94. [CrossRef]

8. Nakov, D.; Hristov, S.; Stankovic, B.; Pol, F.; Dimitrov, I.; Ilieski, V.; Mormede, P.; Hervé, J.; Terenina, E.; Lieubeau, B.; et al. Methodologies for Assessing Disease Tolerance in Pigs. Front. Vet. Sci. 2018, 5, 329. [CrossRef]

9. Berghof, T.V.L.; Poppe, M.; Mulder, H.A. Opportunities to Improve Resilience in Animal Breeding Programs. Front. Genet. 2019, 9, 692. [CrossRef]

10. Valros, A. Chapter 5-Tail biting. In Advances in Pig Welfare; Herd and Flock Welfare; Špinka, M., Ed.; Woodhead Publishing: Cambridge, UK, 2018; pp. 137-166. ISBN 978-0-08-101012-9.

11. D’Eath, R.B.; Arnott, G.; Turner, S.P.; Jensen, T.; Lahrmann, H.P.; Busch, M.E.; Niemi, J.K.; Lawrence, A.B.; Sandøe, P. Injurious tail biting in pigs: How can it be controlled in existing systems without tail docking? Animal 2014, 8, 1479-1497. [CrossRef]

12. Jensen, P.; Buitenhuis, B.; Kjaer, J.; Zanella, A.; Mormède, P.; Pizzari, T. Genetics and genomics of animal behaviour and welfare-Challenges and possibilities. Appl. Anim. Behav. Sci. 2008, 112, 383-403. [CrossRef]

13. Turner, S.P.; Camerlink, I.; Baxter, E.M.; D'Eath, R.B.; Desire, S.; Roehe, R. 14-Breeding for pig welfare: Opportunities and challenges. In Advances in Pig Welfare; Herd and Flock Welfare; Špinka, M., Ed.; Woodhead Publishing: Cambridge, UK, 2018; pp. 399-414. ISBN 978-0-08-101012-9.

14. Kanis, E.; De Greef, K.H.; Hiemstra, A.; van Arendonk, J.A.M. Breeding for societally important traits in pigs. J. Anim. Sci. 2005, 83, 948-957. [CrossRef] [PubMed]

15. Taylor, N.R.; Parker, R.M.A.; Mendl, M.; Edwards, S.A.; Main, D.C.J. Prevalence of risk factors for tail biting on commercial farms and intervention strategies. Vet. J. 2012, 194, 77-83. [CrossRef] [PubMed]

16. Grümpel, A.; Krieter, J.; Dippel, S. Reducing estimated tail biting risk in German weaner pigs using a management tool. Vet. J. 2019, 254, 105406. [CrossRef]

17. Hettinga, K.; Zhang, L. Omics and Systems Biology: Integration of Production and Omics Data in Systems Biology. In Proteomics in Domestic Animals: From Farm to Systems Biology; de Almeida, A.M., Eckersall, D., Miller, I., Eds.; Springer International Publishing: Cham, Switzerland, 2018; pp. 463-485. ISBN 978-3-319-69682-9.

18. van der Steen, H.A.M.; Prall, G.F.W.; Plastow, G.S. Application of genomics to the pork industry. J. Anim. Sci. 2005, 83, E1-E8. [CrossRef]

19. Parreira, J.R.; de Sousa Araújo, S. Studying the Animal Transcriptome: State of the Art and Challenges in the Context of Animal and Veterinary Sciences. In Proteomics in Domestic Animals: From Farm to Systems Biology; de Almeida, A.M., Eckersall, D., Miller, I., Eds.; Springer International Publishing: Cham, Switzerland, 2018; pp. 421-446. ISBN 978-3-319-69682-9.

20. Boyle, E.A.; Li, Y.I.; Pritchard, J.K. An Expanded View of Complex Traits: From Polygenic to Omnigenic. Cell 2017, 169, 1177-1186. [CrossRef]

21. Stamps, J.; Groothuis, T.G.G. The development of animal personality: Relevance, concepts and perspectives. Biol. Rev. 2010, 85, 301-325. [CrossRef]

22. LaFreniere, P.; MacDonald, K. A post-genomic view of behavioral development and adaptation to the environment. Dev. Rev. 2013, 33, 89-109. [CrossRef]

23. Meaney, M.J.; Szyf, M. Maternal care as a model for experience-dependent chromatin plasticity? Trends Neurosci. 2005, 28, 456-463. [CrossRef]

24. Georges, M.; Charlier, C.; Hayes, B. Harnessing genomic information for livestock improvement. Nat. Rev. Genet. 2019, 20, 135-156. [CrossRef] 
25. Moreno-Moral, A.; Petretto, E. From integrative genomics to systems genetics in the rat to link genotypes to phenotypes. Model. Mech. 2016, 9, 1097-1110. [CrossRef]

26. Ritchie, M.D.; Holzinger, E.R.; Li, R.; Pendergrass, S.A.; Kim, D. Methods of integrating data to uncover genotype-phenotype interactions. Nat. Rev. Genet. 2015, 16, 85-97. [CrossRef] [PubMed]

27. Ramos, M.; Schiffer, L.; Re, A.; Azhar, R.; Basunia, A.; Rodriguez, C.; Chan, T.; Chapman, P.; Davis, S.R.; Gomez-Cabrero, D.; et al. Software for the Integration of Multiomics Experiments in Bioconductor. Cancer Res. 2017, 77, e39-e42. [CrossRef] [PubMed]

28. Bersanelli, M.; Mosca, E.; Remondini, D.; Giampieri, E.; Sala, C.; Castellani, G.; Milanesi, L. Methods for the integration of multi-omics data: Mathematical aspects. BMC Bioinform. 2016, 17, S15. [CrossRef]

29. Tini, G.; Marchetti, L.; Priami, C.; Scott-Boyer, M.-P. Multi-omics integration-A comparison of unsupervised clustering methodologies. Brief. Bioinform. 2019, 20, 1269-1279. [CrossRef]

30. Subramanian, I.; Verma, S.; Kumar, S.; Jere, A.; Anamika, K. Multi-omics Data Integration, Interpretation, and Its Application. Bioinform. Biol. Insights 2020, 14, 1177932219899051. [CrossRef]

31. Montastier, E.; Villa-Vialaneix, N.; Caspar-Bauguil, S.; Hlavaty, P.; Tvrzicka, E.; Gonzalez, I.; Saris, W.H.M.; Langin, D.; Kunesova, M.; Viguerie, N. System model network for adipose tissue signatures related to weight changes in response to calorie restriction and subsequent weight maintenance. PLoS Comput. Biol. 2015, 11, e1004047. [CrossRef]

32. Chaudhary, K.; Poirion, O.B.; Lu, L.; Garmire, L.X. Deep Learning-Based Multi-Omics Integration Robustly Predicts Survival in Liver Cancer. Clin. Cancer Res. 2018, 24, 1248-1259. [CrossRef]

33. Shannon, P.; Markiel, A.; Ozier, O.; Baliga, N.S.; Wang, J.T.; Ramage, D.; Amin, N.; Schwikowski, B.; Ideker, T. Cytoscape: A Software Environment for Integrated Models of Biomolecular Interaction Networks. Genome Res. 2003, 13, 2498-2504. [CrossRef]

34. Argelaguet, R.; Velten, B.; Arnol, D.; Dietrich, S.; Zenz, T.; Marioni, J.C.; Buettner, F.; Huber, W.; Stegle, O. Multi-Omics Factor Analysis-A framework for unsupervised integration of multi-omics data sets. Mol. Syst. Biol. 2018, 14, e8124. [CrossRef]

35. Peng, C.; Wang, J.; Asante, I.; Louie, S.; Jin, R.; Chatzi, L.; Casey, G.; Thomas, D.C.; Conti, D.V. A latent unknown clustering integrating multi-omics data (LUCID) with phenotypic traits. Bioinformatics 2020, 36, 842-850. [CrossRef] [PubMed]

36. Hernandez-Ferrer, C.; Ruiz-Arenas, C.; Beltran-Gomila, A.; González, J.R. MultiDataSet: An R package for encapsulating multiple data sets with application to omic data integration. BMC Bioinform. 2017, 18, 36. [CrossRef] [PubMed]

37. Fukunaga, T.; Iwasaki, W. Logicome Profiler: Exhaustive detection of statistically significant logic relationships from comparative omics data. PLoS ONE 2020, 15, e0232106. [CrossRef] [PubMed]

38. Shang, L.; Smith, J.A.; Zhou, X. Leveraging gene co-expression patterns to infer trait-relevant tissues in genome-wide association studies. PLOS Genet. 2020, 16, e1008734. [CrossRef] [PubMed]

39. Aten, J.E.; Fuller, T.F.; Lusis, A.J.; Horvath, S. Using genetic markers to orient the edges in quantitative trait networks: The NEO software. BMC Syst. Biol. 2008, 2, 34. [CrossRef]

40. Zhang, B.; Horvath, S. A General Framework for Weighted Gene Co-Expression Network Analysis. Stat. Appl. Genet. Mol. Biol. 2005, 4. [CrossRef]

41. Langfelder, P.; Horvath, S. WGCNA: An R package for weighted correlation network analysis. BMC Bioinformatics 2008, 9, 559. [CrossRef]

42. Rohart, F.; Gautier, B.; Singh, A.; Cao, K.-A.L. mixOmics: An R package for 'omics feature selection and multiple data integration. PLOS Comput. Biol. 2017, 13, e1005752. [CrossRef]

43. Tenenhaus, A.; Philippe, C.; Guillemot, V.; Le Cao, K.-A.; Grill, J.; Frouin, V. Variable selection for generalized canonical correlation analysis. Biostatistics 2014, 15, 569-583. [CrossRef]

44. Singh, A.; Shannon, C.P.; Gautier, B.; Rohart, F.; Vacher, M.; Tebbutt, S.J.; Lê Cao, K.-A. DIABLO: An integrative approach for identifying key molecular drivers from multi-omics assays. Bioinformatics 2019, 35, 3055-3062. [CrossRef]

45. Martinez-Miro, S.; Tecles, F.; Ramon, M.; Escribano, D.; Hernandez, F.; Madrid, J.; Orengo, J.; Martinez-Subiela, S.; Manteca, X.; Joaquin Ceron, J. Causes, consequences and biomarkers of stress in swine: An update. BMC Vet. Res. 2016, 12, 171. [CrossRef] [PubMed]

46. Gimsa, U.; Tuchscherer, M.; Kanitz, E. Psychosocial Stress and Immunity-What Can We Learn From Pig Studies? Front. Behav. Neurosci. 2018, 12, 64. [CrossRef] [PubMed] 
47. Marco-Ramell, A.; de Almeida, A.M.; Cristobal, S.; Rodrigues, P.; Roncada, P.; Bassols, A. Proteomics and the search for welfare and stress biomarkers in animal production in the one-health context. Mol. Biosyst. 2018, 12, 2024-2035. [CrossRef] [PubMed]

48. Goldstein, D.S. Computer Models of Stress, Allostasis, and Acute and Chronic Diseases. Ann. N. Y. Acad. Sci. 2008, 1148, 223-231. [CrossRef] [PubMed]

49. Franco, D.; Mato, A.; Salgado, F.J.; López-Pedrouso, M.; Carrera, M.; Bravo, S.; Parrado, M.; Gallardo, J.M.; Zapata, C. Tackling proteome changes in the longissimus thoracis bovine muscle in response to pre-slaughter stress. J. Proteomics 2015, 122, 73-85. [CrossRef] [PubMed]

50. Mato, A.; Rodríguez-Vázquez, R.; López-Pedrouso, M.; Bravo, S.; Franco, D.; Zapata, C. The first evidence of global meat phosphoproteome changes in response to pre-slaughter stress. BMC Genom. 2019, 20, 590. [CrossRef]

51. Fuente-Garcia, C.; Aldai, N.; Sentandreu, E.; Oliván, M.; García-Torres, S.; Franco, D.; Zapata, C.; Sentandreu, M.A. Search for proteomic biomarkers related to bovine pre-slaughter stress using liquid isoelectric focusing (OFFGEL) and mass spectrometry. J. Proteom. 2019, 198, 59-65. [CrossRef]

52. Li, J.; Wijffels, G.; Yu, Y.; Nielsen, L.K.; Niemeyer, D.O.; Fisher, A.D.; Ferguson, D.M.; Schirra, H.J. Altered fatty acid metabolism in long duration road transport: An NMR-based metabonomics study in sheep. J. Proteome Res. 2011, 10, 1073-1087. [CrossRef]

53. Hao, Y.; Feng, Y.; Yang, P.; Cui, Y.; Liu, J.; Yang, C.; Gu, X. Transcriptome analysis reveals that constant heat stress modifies the metabolism and structure of the porcine longissimus dorsi skeletal muscle. Mol. Genet. Genom. 2016, 291, 2101-2115. [CrossRef]

54. Cui, Y.; Hao, Y.; Li, J.; Bao, W.; Li, G.; Gao, Y.; Gu, X. Chronic Heat Stress Induces Immune Response, Oxidative Stress Response, and Apoptosis of Finishing Pig Liver: A Proteomic Approach. Int. J. Mol. Sci. 2016, 17, 393. [CrossRef]

55. Qu, H.; Ajuwon, K.M. Metabolomics of heat stress response in pig adipose tissue reveals alteration of phospholipid and fatty acid composition during heat stress1. J. Anim. Sci. 2018. [CrossRef] [PubMed]

56. Sandercock, D.A.; Barnett, M.W.; Coe, J.E.; Downing, A.C.; Nirmal, A.J.; Di Giminiani, P.; Edwards, S.A.; Freeman, T.C. Transcriptomics Analysis of Porcine Caudal Dorsal Root Ganglia in Tail Amputated Pigs Shows Long-Term Effects on Many Pain-Associated Genes. Front. Vet. Sci. 2019, 6, 314. [CrossRef] [PubMed]

57. Escribano, D.; Horvatić, A.; Contreras-Aguilar, M.D.; Guillemin, N.; Cerón, J.J.; Tecles, F.; Martinez-Miró, S.; Eckersall, P.D.; Manteca, X.; Mrljak, V. Changes in saliva proteins in two conditions of compromised welfare in pigs: An experimental induced stress by nose snaring and lameness. Res. Vet. Sci. 2019, 125, 227-234. [CrossRef]

58. de Almeida, A.M.; Bendixen, E. Pig proteomics: A review of a species in the crossroad between biomedical and food sciences. J. Proteom. 2012, 75, 4296-4314. [CrossRef]

59. Lamy, E.; Mau, M. Saliva proteomics as an emerging, non-invasive tool to study livestock physiology, nutrition and diseases. J. Proteom. 2012, 75, 4251-4258. [CrossRef]

60. Redei, E.E. Molecular genetics of the stress-responsive adrenocortical axis. Ann. Med. 2008, 40, 139-148. [CrossRef] [PubMed]

61. Murani, E.; Reyer, H.; Ponsuksili, S.; Fritschka, S.; Wimmers, K. A substitution in the ligand binding domain of the porcine glucocorticoid receptor affects activity of the adrenal gland. PLOS ONE 2012, 7, e45518. [CrossRef] [PubMed]

62. Rauw, W.M.; Johnson, A.K.; Gomez-Raya, L.; Dekkers, J.C.M. A Hypothesis and Review of the Relationship between Selection for Improved Production Efficiency, Coping Behavior, and Domestication. Front. Genet. 2017, 8, 134. [CrossRef]

63. Ruis, M.A.W.; te Brake, J.H.A.; Engel, B.; Buist, W.G.; Blokhuis, H.J.; Koolhaas, J.M. Adaptation to social isolation: Acute and long-term stress responses of growing gilts with different coping characteristics. Physiol. Behav. 2001, 73, 541-551. [CrossRef]

64. Smolinska, A.; Blanchet, L.; Buydens, L.M.C.; Wijmenga, S.S. NMR and pattern recognition methods in metabolomics: From data acquisition to biomarker discovery: A review. Anal. Chim. Acta 2012, 750, 82-97. [CrossRef]

65. Mischak, H.; Allmaier, G.; Apweiler, R.; Attwood, T.; Baumann, M.; Benigni, A.; Bennett, S.E.; Bischoff, R.; Bongcam-Rudloff, E.; Capasso, G.; et al. Recommendations for Biomarker Identification and Qualification in Clinical Proteomics. Sci. Transl. Med. 2010, 2, 46ps42. [CrossRef] [PubMed] 
66. Liu, D.; Diorio, J.; Tannenbaum, B.; Caldji, C.; Francis, D.; Freedman, A.; Sharma, S.; Pearson, D.; Plotsky, P.M.; Meaney, M.J. Maternal Care, Hippocampal Glucocorticoid Receptors, and Hypothalamic-Pituitary-Adrenal Responses to Stress. Science 1997, 277, 1659-1662. [CrossRef] [PubMed]

67. Weaver, I.C.G.; Meaney, M.J.; Szyf, M. Maternal care effects on the hippocampal transcriptome and anxiety-mediated behaviors in the offspring that are reversible in adulthood. Proc. Natl. Acad. Sci. USA 2006, 103, 3480-3485. [CrossRef] [PubMed]

68. Suderman, M.; McGowan, P.O.; Sasaki, A.; Huang, T.C.T.; Hallett, M.T.; Meaney, M.J.; Turecki, G.; Szyf, M. Conserved epigenetic sensitivity to early life experience in the rat and human hippocampus. Proc. Natl. Acad. Sci. USA 2012, 109, 17266-17272. [CrossRef] [PubMed]

69. García-Giménez, J.L.; Seco-Cervera, M.; Tollefsbol, T.O.; Romá-Mateo, C.; Peiró-Chova, L.; Lapunzina, P.; Pallardó, F.V. Epigenetic biomarkers: Current strategies and future challenges for their use in the clinical laboratory. Crit. Rev. Clin. Lab. Sci. 2017, 54, 529-550. [CrossRef] [PubMed]

70. Ritsner, M.S.; Gottesman, I.I. Where Do We Stand in the Quest for Neuropsychiatric Biomarkers and Endophenotypes and What Next. In The Handbook of Neuropsychiatric Biomarkers, Endophenotypes and Genes: Neuropsychological Endophenotypes and Biomarkers; Ritsner, M.S., Ed.; Springer: Dordrecht, The Netherlands, 2009; pp. 3-21. ISBN 978-1-4020-9464-4.

71. Logue, M.W.; Miller, M.W.; Wolf, E.J.; Huber, B.R.; Morrison, F.G.; Zhou, Z.; Zheng, Y.; Smith, A.K.; Daskalakis, N.P.; Ratanatharathorn, A.; et al. An epigenome-wide association study of posttraumatic stress disorder in US veterans implicates several new DNA methylation loci. Clin. Epigenet. 2020, 12, 46. [CrossRef]

72. Otten, W.; Kanitz, E.; Tuchscherer, M. The impact of pre-natal stress on offspring development in pigs. J. Agric. Sci. 2015, 153, 907-919. [CrossRef]

73. Schachtschneider, K.M.; Welge, M.E.; Auvil, L.S.; Chaki, S.; Rund, L.A.; Madsen, O.; Elmore, M.R.P.; Johnson, R.W.; Groenen, M.A.M.; Schook, L.B. Altered Hippocampal Epigenetic Regulation Underlying Reduced Cognitive Development in Response to Early Life Environmental Insults. Genes 2020, 11, 162. [CrossRef]

74. Chen, R.J.; Kelly, G.; Sengupta, A.; Heydendael, W.; Nicholas, B.; Beltrami, S.; Luz, S.; Peixoto, L.; Abel, T.; Bhatnagar, S. MicroRNAs as biomarkers of resilience or vulnerability to stress. Neuroscience 2015, 305, 36-48. [CrossRef]

75. Schmidt, U.; Keck, M.E.; Buell, D.R. miRNAs and other non-coding RNAs in posttraumatic stress disorder: A systematic review of clinical and animal studies. J. Psychiatr. Res. 2015, 65, 1-8. [CrossRef]

76. Lecchi, C.; Zamarian, V.; Gini, C.; Avanzini, C.; Polloni, A.; Rota Nodari, S.; Ceciliani, F. Salivary microRNAs are potential biomarkers for the accurate and precise identification of inflammatory response after tail docking and castration in piglets. J. Anim. Sci. 2020, 98. [CrossRef] [PubMed]

77. Schöler, N.; Langer, C.; Döhner, H.; Buske, C.; Kuchenbauer, F. Serum microRNAs as a novel class of biomarkers: A comprehensive review of the literature. Exp. Hematol. 2010, 38, 1126-1130. [CrossRef] [PubMed]

78. Ai, S.; Shen, L.; Guo, J.; Feng, X.; Tang, B. DNA Methylation as a Biomarker for Neuropsychiatric Diseases. Int. J. Neurosci. 2012, 122, 165-176. [CrossRef] [PubMed]

79. Guidotti, A.; Auta, J.; Davis, J.M.; Dong, E.; Gavin, D.P.; Grayson, D.R.; Sharma, R.P.; Smith, R.C.; Tueting, P.; Zhubi, A. Toward the Identification of Peripheral Epigenetic Biomarkers of Schizophrenia. J. Neurogenet. 2014, 28, 41-52. [CrossRef]

80. Ahanda, M.-L.E.; Zerjal, T.; Dhorne-Pollet, S.; Rau, A.; Cooksey, A.; Giuffra, E. Impact of the Genetic Background on the Composition of the Chicken Plasma MiRNome in Response to a Stress. PLoS ONE 2014, 9, e114598. [CrossRef] [PubMed]

81. Ioannidis, J.; Sánchez-Molano, E.; Psifidi, A.; Donadeu, F.X.; Banos, G. Association of plasma microRNA expression with age, genetic background and functional traits in dairy cattle. Sci. Rep. 2018, 8, 12955. [CrossRef]

82. Murani, E.; Trakooljul, N.; Hadlich, F.; Ponsuksili, S.; Wimmers, K. Transcriptome Responses to Dexamethasone Depending on Dose and Glucocorticoid Receptor Sensitivity in the Liver. Front. Genet. 2019, 10. [CrossRef]

83. Bianco, E.; Nevado, B.; Ramos-Onsins, S.E.; Pérez-Enciso, M. A Deep Catalog of Autosomal Single Nucleotide Variation in the Pig. PLoS ONE 2015, 10, e0118867. [CrossRef]

84. Weiler, U.; Claus, R.; Schnoebelen-Combes, S.; Louveau, I. Influence of age and genotype on endocrine parameters and growth performance: A comparative study in Wild boars, Meishan and Large White boars. Livest. Prod. Sci. 1998, 54, 21-31. [CrossRef] 
85. Künzl, C.; Sachser, N. The Behavioral Endocrinology of Domestication: A Comparison between the Domestic Guinea Pig (Cavia apereaf.porcellus) and Its Wild Ancestor, the Cavy (Cavia aperea). Horm. Behav. 1999, 35, 28-37. [CrossRef]

86. Malmkvist, J.; Hansen, S.W. The Welfare of Farmed Mink (Mustela Vison) in Relation to Behavioural Selection: A Review. Available online: https://www.ingentaconnect.com/content/ufaw/aw/2001/00000010/00000001/ art00004 (accessed on 11 May 2020).

87. Albert, F.W.; Carlborg, Ö.; Plyusnina, I.; Besnier, F.; Hedwig, D.; Lautenschläger, S.; Lorenz, D.; McIntosh, J.; Neumann, C.; Richter, H.; et al. Genetic Architecture of Tameness in a Rat Model of Animal Domestication. Genetics 2009, 182, 541-554. [CrossRef] [PubMed]

88. Trut, L.; Oskina, I.; Kharlamova, A. Animal evolution during domestication: The domesticated fox as a model. Bioessays 2009, 31, 349-360. [CrossRef] [PubMed]

89. Kadmiel, M.; Cidlowski, J.A. Glucocorticoid receptor signaling in health and disease. Trends Pharmacol. Sci. 2013, 34, 518-530. [CrossRef] [PubMed]

90. Elsaesser, F.; Pfaffl, M.W.; Meyer, H.H.D.; Serpek, B.; Sauerwein, H. Differences in the somatotropic axis, in blood cortisol, insulin and thyroid hormone concentrations between two pig genotypes with markedly divergent growth rates and the effects of growth hormone treatment. Anim. Sci. 2002, 74, 423-430. [CrossRef]

91. Foury, A.; Geverink, N.A.; Gil, M.; Gispert, M.; Hortós, M.; Furnols, M.F.I.; Carrion, D.; Blott, S.C.; Plastow, G.S.; Mormède, P. Stress neuroendocrine profiles in five pig breeding lines and the relationship with carcass composition. Animal 2007, 1, 973-982. [CrossRef]

92. Colpoys, J.; Van Sambeek, D.; Bruns, C.; Johnson, A.; Dekkers, J.; Dunshea, F.; Gabler, N. Responsiveness of swine divergently selected for feed efficiency to exogenous adrenocorticotropic hormone and glucose challenges. Domest. Anim. Endocrinol. 2018, 68, 32-38. [CrossRef]

93. Leenhouwers, J.I.; Knol, E.F.; de Groot, P.N.; Vos, H.; van der Lende, T. Fetal development in the pig in relation to genetic merit for piglet survival. J. Anim. Sci. 2002, 80, 1759-1770. [CrossRef]

94. Leenhouwers, J.I.; Knol, E.F.; van der Lende, T. Differences in late prenatal development as an explanation for genetic differences in piglet survival. Livest. Prod. Sci. 2002, 78, 57-62. [CrossRef]

95. Lebret, B.; Ecolan, P.; Bonhomme, N.; Meteau, K.; Prunier, A. Influence of production system in local and conventional pig breeds on stress indicators at slaughter, muscle and meat traits and pork eating quality. Animal 2015, 9, 1404-1413. [CrossRef]

96. Devillers, N.; Le Dividich, J.; Prunier, A. Influence of colostrum intake on piglet survival and immunity. Animal 2011, 5, 1605-1612. [CrossRef]

97. Kadarmideen, H.N.; Janss, L.L.G. Population and systems genetics analyses of cortisol in pigs divergently selected for stress. Physiol. Genom. 2007, 29, 57-65. [CrossRef] [PubMed]

98. Larzul, C.; Terenina, E.; Foury, A.; Billon, Y.; Louveau, I.; Merlot, E.; Mormede, P. The cortisol response to ACTH in pigs, heritability and influence of corticosteroid-binding globulin. Animal 2015, 9, 1929-1934. [CrossRef]

99. Désautés, C.; Bidanel, J.P.; Milan, D.; Iannuccelli, N.; Amigues, Y.; Bourgeois, F.; Caritez, J.C.; Renard, C.; Chevalet, C.; Mormède, P. Genetic linkage mapping of quantitative trait loci for behavioral and neuroendocrine stress response traits in pigs. J. Anim. Sci. 2002, 80, 2276-2285. [CrossRef] [PubMed]

100. Sanchez, M.P.; Iannuccelli, N.; Basso, B.; Foury, A.; Billon, Y.; Gandemer, G.; Gilbert, H.; Mormède, P.; Bidanel, J.P.; Larzul, C.; et al. Microsatellite mapping of quantitative trait loci affecting meat quality, stress hormones and production traits in Duroc $\times$ Large White F2 pigs. Animal 2011, 5, 167-174. [CrossRef] [PubMed]

101. Okamura, T.; Onodera, W.; Tayama, T.; Kadowaki, H.; Kojima-Shibata, C.; Suzuki, E.; Uemoto, Y.; Mikawa, S.; Hayashi, T.; Awata, T.; et al. A genome-wide scan for quantitative trait loci affecting respiratory disease and immune capacity in Landrace pigs. Anim. Genet. 2012, 43, 721-729. [CrossRef] [PubMed]

102. Muráni, E.; Ponsuksili, S.; D’Eath, R.B.; Turner, S.P.; Kurt, E.; Evans, G.; Thölking, L.; Klont, R.; Foury, A.; Mormède, P.; et al. Association of HPA axis-related genetic variation with stress reactivity and aggressive behaviour in pigs. BMC Genet. 2010, 11, 74. [CrossRef]

103. Ponsuksili, S.; Du, Y.; Murani, E.; Schwerin, M.; Wimmers, K. Elucidating molecular networks that either affect or respond to plasma cortisol concentration in target tissues of liver and muscle. Genetics 2012, 192, 1109-1122. [CrossRef]

104. Hessing, M.J.; Hagelsø, A.M.; Schouten, W.G.; Wiepkema, P.R.; van Beek, J.A. Individual behavioral and physiological strategies in pigs. Physiol. Behav. 1994, 55, 39-46. [CrossRef] 
105. Zebunke, M.; Repsilber, D.; Nuernberg, G.; Wittenburg, D.; Puppe, B. The backtest in pigs revisited-An analysis of intra-situational behaviour. Appl. Anim. Behav. Sci. 2015, 169, 17-25. [CrossRef]

106. Rohrer, G.A.; Brown-Brandl, T.; Rempel, L.A.; Schneider, J.F.; Holl, J. Genetic analysis of behavior traits in swine production. Livest. Sci. 2013, 157, 28-37. [CrossRef]

107. Scheffler, K.; Stamer, E.; Traulsen, I.; Krieter, J. Genetic analysis of the individual pig behaviour in backtests and human approach tests. Appl. Anim. Behav. Sci. 2014, 160, 38-45. [CrossRef]

108. Velie, B.D.; Maltecca, C.; Cassady, J.P. Genetic relationships among pig behavior, growth, backfat, and loin muscle area. J. Anim. Sci. 2009, 87, 2767-2773. [CrossRef] [PubMed]

109. Ponsuksili, S.; Zebunke, M.; Murani, E.; Trakooljul, N.; Krieter, J.; Puppe, B.; Schwerin, M.; Wimmers, K. Integrated Genome-wide association and hypothalamus eQTL studies indicate a link between the circadian rhythm-related gene PER1 and coping behavior. Sci. Rep. 2015, 5, 1-14. [CrossRef]

110. Putz, A.M.; Harding, J.C.S.; Dyck, M.K.; Fortin, F.; Plastow, G.S.; Dekkers, J.C.M.; Canada, P. Novel Resilience Phenotypes Using Feed Intake Data from a Natural Disease Challenge Model in Wean-to-Finish Pigs. Front. Genet. 2018, 9, 660. [CrossRef] [PubMed]

111. Cross, A.J.; Keel, B.N.; Brown-Brandl, T.M.; Cassady, J.P.; Rohrer, G.A. Genome-wide association of changes in swine feeding behaviour due to heat stress. Genet. Sel. Evol. 2018, 50, 11. [CrossRef] [PubMed]

112. Reyer, H.; Ponsuksili, S.; Kanitz, E.; Pöhland, R.; Wimmers, K.; Murani, E. A Natural Mutation in Helix 5 of the Ligand Binding Domain of Glucocorticoid Receptor Enhances Receptor-Ligand Interaction. PLoS ONE 2016, 11, e0164628. [CrossRef]

113. Muráni, E.; Ponsuksili, S.; Jaeger, A.; Görres, A.; Tuchscherer, A.; Wimmers, K. A naturally hypersensitive glucocorticoid receptor elicits a compensatory reduction of hypothalamus-pituitary-adrenal axis activity early in ontogeny. Open Biol. 2016, 6, 150193. [CrossRef]

114. Ousova, O.; Guyonnet-Duperat, V.; Iannuccelli, N.; Bidanel, J.-P.; Milan, D.; Genêt, C.; Llamas, B.; Yerle, M.; Gellin, J.; Chardon, P.; et al. Corticosteroid Binding Globulin: A New Target for Cortisol-Driven Obesity. Mol. Endocrinol. 2004, 18, 1687-1696. [CrossRef]

115. Esteve, A.; Ojeda, A.; Huang, L.S.; Folch, J.M.; Pérez-Enciso, M. Nucleotide variability of the porcine SERPINA6 gene and the origin of a putative causal mutation associated with meat quality. Anim. Genet. 2011, 42, 235-241. [CrossRef]

116. Guyonnet-Dupérat, V.; Geverink, N.; Plastow, G.S.; Evans, G.; Ousova, O.; Croisetière, C.; Foury, A.; Richard, E.; Mormède, P.; Moisan, M.-P. Functional Implication of an Arg307Gly Substitution in Corticosteroid-Binding Globulin, a Candidate Gene for a Quantitative Trait Locus Associated with Cortisol Variability and Obesity in Pig. Genetics 2006, 173, 2143-2149. [CrossRef]

117. Görres, A.; Ponsuksili, S.; Wimmers, K.; Muráni, E. Analysis of non-synonymous SNPs of the porcine SERPINA6 gene as potential causal variants for a QTL affecting plasma cortisol levels on SSC7. Anim. Genet. 2015, 46, 239-246. [CrossRef] [PubMed]

118. Daetwyler, H.D.; Capitan, A.; Pausch, H.; Stothard, P.; van Binsbergen, R.; Brøndum, R.F.; Liao, X.; Djari, A.; Rodriguez, S.C.; Grohs, C.; et al. Whole-genome sequencing of 234 bulls facilitates mapping of monogenic and complex traits in cattle. Nat. Genet. 2014, 46, 858. [CrossRef] [PubMed]

119. Keane, T.M.; Goodstadt, L.; Danecek, P.; White, M.A.; Wong, K.; Yalcin, B.; Heger, A.; Agam, A.; Slater, G.; Goodson, M.; et al. Mouse genomic variation and its effect on phenotypes and gene regulation. Nature 2011, 477, 289-294. [CrossRef]

120. Nicolae, D.L.; Gamazon, E.; Zhang, W.; Duan, S.; Dolan, M.E.; Cox, N.J. Trait-associated SNPs are more likely to be eQTLs: Annotation to enhance discovery from GWAS. PLoS Genet. 2010, 6, e1000888. [CrossRef]

121. Albert, F.W.; Kruglyak, L. The role of regulatory variation in complex traits and disease. Nat. Rev. Genet. 2015, 16, 197-212. [CrossRef]

122. Emilsson, V.; Thorleifsson, G.; Zhang, B.; Leonardson, A.S.; Zink, F.; Zhu, J.; Carlson, S.; Helgason, A.; Walters, G.B.; Gunnarsdottir, S.; et al. Genetics of gene expression and its effect on disease. Nature 2008, 452, 423-428. [CrossRef]

123. Schadt, E.E. Novel integrative genomics strategies to identify genes for complex traits. Anim. Genet. 2006, 37, 18-23. [CrossRef]

124. Jansen, R.C.; Nap, J.-P. Genetical genomics: The added value from segregation. Trends Genet. 2001, 17, 388-391. [CrossRef] 
125. Gamazon, E.R.; Ziliak, D.; Im, H.K.; LaCroix, B.; Park, D.S.; Cox, N.J.; Huang, R.S. Genetic Architecture of MicroRNA Expression: Implications for the Transcriptome and Complex Traits. Am. J. Hum. Genet. 2012, 90, 1046-1063. [CrossRef]

126. Murani, E.; Ponsuksili, S.; Reyer, H.; Wittenburg, D.; Wimmers, K. Expression variation of the porcine ADRB2 has a complex genetic background. Mol. Genet. Genom. 2013, 288, 615-625. [CrossRef]

127. Jaeger, A.; Fritschka, S.; Ponsuksili, S.; Wimmers, K.; Muráni, E. Identification and Functional Characterization of Cis-Regulatory Elements Controlling Expression of the Porcine ADRB2 Gene. Int. J. Biol. Sci. 2015, 11, 1006-1015. [CrossRef] [PubMed]

128. Giuffra, E.; Tuggle, C.K.; Consortium, T.F. Functional Annotation of Animal Genomes (FAANG): Current Achievements and Roadmap. Annu. Rev. Anim. Biosci. 2019, 17, 65-88. [CrossRef] [PubMed]

129. Groß, C.; Derks, M.; Megens, H.-J.; Bosse, M.; Groenen, M.A.M.; Reinders, M.; de Ridder, D. pCADD: SNV prioritisation in Sus scrofa. Genet. Sel. Evol. 2020, 52, 4. [CrossRef] [PubMed]

130. Gao, N.; Martini, J.W.R.; Zhang, Z.; Yuan, X.; Zhang, H.; Simianer, H.; Li, J. Incorporating Gene Annotation into Genomic Prediction of Complex Phenotypes. Genetics 2017, 207, 489-501. [CrossRef] [PubMed]

131. Cai, Z.; Guldbrandtsen, B.; Lund, M.S.; Sahana, G. Weighting sequence variants based on their annotation increases the power of genome-wide association studies in dairy cattle. Genet. Sel. Evol. 2019, 51, 20. [CrossRef] [PubMed]

132. Cowles, C.R.; Hirschhorn, J.N.; Altshuler, D.; Lander, E.S. Detection of regulatory variation in mouse genes. Nat. Genet. 2002, 32, 432-437. [CrossRef] [PubMed]

133. Maroilley, T.; Lemonnier, G.; Lecardonnel, J.; Esquerré, D.; Ramayo-Caldas, Y.; Mercat, M.J.; Rogel-Gaillard, C.; Estellé, J. Deciphering the genetic regulation of peripheral blood transcriptome in pigs through expression genome-wide association study and allele-specific expression analysis. BMC Genom. 2017, 18, 967. [CrossRef]

134. Crowley, J.J.; Zhabotynsky, V.; Sun, W.; Huang, S.; Pakatci, I.K.; Kim, Y.; Wang, J.R.; Morgan, A.P.; Calaway, J.D.; Aylor, D.L.; et al. Analyses of allele-specific gene expression in highly divergent mouse crosses identifies pervasive allelic imbalance. Nat. Genet. 2015, 47, 353-360. [CrossRef]

135. Brunberg, E.I.; Rodenburg, T.B.; Rydhmer, L.; Kjaer, J.B.; Jensen, P.; Keeling, L.J. Omnivores Going Astray: A Review and New Synthesis of Abnormal Behavior in Pigs and Laying Hens. Front. Vet. Sci. 2016, 3. [CrossRef]

136. Nalon, E.; De Briyne, N. Efforts to Ban the Routine Tail Docking of Pigs and to Give Pigs Enrichment Materials via EU Law: Where Do We Stand a Quarter of a Century on? Animals 2019, 9, 132. [CrossRef]

137. EFSA. Scientific report on the risks associated with tail biting in pigs and possible means to reduce the need for tail docking considering the different housing and husbandry systems. EFSA J. 2007, 5, 611. [CrossRef]

138. Sinisalo, A.; Niemi, J.K.; Heinonen, M.; Valros, A. Tail biting and production performance in fattening pigs. Livest. Sci. 2012, 143, 220-225. [CrossRef]

139. Breuer, K.; Sutcliffe, M.E.M.; Mercer, J.T.; Rance, K.A.; Beattie, V.E.; Sneddon, I.A.; Edwards, S.A. The effect of breed on the development of adverse social behaviours in pigs. Appl. Anim. Behav. Sci. 2003, 84, 59-74. [CrossRef]

140. Moinard, C.; Mendl, M.; Nicol, C.J.; Green, L.E. A case control study of on-farm risk factors for tail biting in pigs. Appl. Anim. Behav. Sci. 2003, 81, 333-355. [CrossRef]

141. Brunberg, E. Tail Biting and Feather Pecking. Available online: https://pub.epsilon.slu.se/8319/ (accessed on 17 June 2020).

142. Wurtz, K.E.; Siegford, J.M.; Ernst, C.W.; Raney, N.E.; Bates, R.O.; Steibel, J.P. Genome-wide association analyses of lesion counts in group-housed pigs. Anim. Genet. 2018, 49, 628-631. [CrossRef] [PubMed]

143. Wilson, K.; Zanella, R.; Ventura, C.; Johansen, H.L.; Framstad, T.; Janczak, A.; Zanella, A.J.; Neibergs, H.L. Identification of chromosomal locations associated with tail biting and being a victim of tail-biting behaviour in the domestic pig (Sus scrofa domesticus). J. Appl. Genet. 2012, 53, 449-456. [CrossRef]

144. Wang, Y.; Cheng, C.; Zhang, Z.; Wang, J.; Wang, Y.; Li, X.; Gao, R.; Wang, Z.; Fang, Y.; Wang, J.; et al. Blood-based dynamic genomic signature for obsessive-compulsive disorder. Am. J. Med. Genet. B Neuropsychiatr. Genet. 2018, 177, 709-716. [CrossRef]

145. Zhang-James, Y.; Fernàndez-Castillo, N.; Hess, J.L.; Malki, K.; Glatt, S.J.; Cormand, B.; Faraone, S.V. An integrated analysis of genes and functional pathways for aggression in human and rodent models. Mol. Psychiatry 2019, 24, 1655-1667. [CrossRef]

146. Fogel, B.L.; Wexler, E.; Wahnich, A.; Friedrich, T.; Vijayendran, C.; Gao, F.; Parikshak, N.; Konopka, G.; Geschwind, D.H. RBFOX1 regulates both splicing and transcriptional networks in human neuronal development. Hum. Mol. Genet. 2012, 21, 4171-4186. [CrossRef] 
147. Fernàndez-Castillo, N.; Gan, G.; van Donkelaar, M.M.J.; Vaht, M.; Weber, H.; Retz, W.; Meyer-Lindenberg, A.; Franke, B.; Harro, J.; Reif, A.; et al. RBFOX1, encoding a splicing regulator, is a candidate gene for aggressive behavior. Eur. Neuropsychopharmacol. 2020, 30, 44-55. [CrossRef]

148. Brunberg, E.; Jensen, P.; Isaksson, A.; Keeling, L.J. Behavioural and Brain Gene Expression Profiling in Pigs during Tail Biting Outbreaks—Evidence of a Tail Biting Resistant Phenotype. PLoS ONE 2013, 8, e66513. [CrossRef] [PubMed]

149. Brunberg, E.; Jensen, P.; Isaksson, A.; Keeling, L.J. Brain gene expression differences are associated with abnormal tail biting behavior in pigs: Gene expression and abnormal behavior in pigs. Genes Brain Behav. 2013, 12, 275-281. [CrossRef] [PubMed]

150. Lan, J.; Lei, M.G.; Zhang, Y.B.; Wang, J.H.; Feng, X.T.; Xu, D.Q.; Gui, J.F.; Xiong, Y.Z. Characterization of the porcine differentially expressed PDK4 gene and association with meat quality. Mol. Biol. Rep. 2009, 36, 2003-2010. [CrossRef] [PubMed]

151. Sakurai, T.; Dorr, N.P.; Takahashi, N.; McInnes, L.A.; Elder, G.A.; Buxbaum, J.D. Haploinsufficiency of Gtf2i, a gene deleted in Williams Syndrome, leads to increases in social interactions. Autism Res. 2011, 4, 28-39. [CrossRef]

152. Hao, Y.; Liu, J.R.; Zhang, Y.; Yang, P.G.; Feng, Y.J.; Cui, Y.J.; Yang, C.H.; Gu, X.H. The microRNA expression profile in porcine skeletal muscle is changed by constant heat stress. Anim. Genet. 2016, 47, 365-369. [CrossRef] [PubMed]

153. Keltikangas-Jarvinen, L.; Puttonen, S.; Kivimaki, M.; Rontu, R.; Lehtimaki, T. Cloninger's temperament dimensions and epidermal growth factor A61G polymorphism in Finnish adults. Genes Brain Behav. 2006, 5, 11-18. [CrossRef]

154. Brunberg, E.; Jensen, P.; Isaksson, A.; Keeling, L. Feather pecking behavior in laying hens: Hypothalamic gene expression in birds performing and receiving pecks. Poult. Sci. 2011, 90, 1145-1152. [CrossRef]

155. Štrac, D.Š.; Pivac, N.; Mück-Šeler, D. The serotonergic system and cognitive function. Transl. Neurosci. 2016, 7, 35-49. [CrossRef]

156. Pani, L.; Porcella, A.; Gessa, G.L. The role of stress in the pathophysiology of the dopaminergic system. Mol. Psychiatry 2000, 5, 14-21. [CrossRef]

157. Pezze, M.A.; Feldon, J. Mesolimbic dopaminergic pathways in fear conditioning. Prog. Neurobiol. 2004, 74, 301-320. [CrossRef]

158. Ursinus, W.W.; Van Reenen, C.G.; Reimert, I.; Bolhuis, J.E. Tail biting in pigs: Blood serotonin and fearfulness as pieces of the puzzle? PLoS ONE 2014, 9, e107040. [CrossRef] [PubMed]

159. Valros, A.; Palander, P.; Heinonen, M.; Munsterhjelm, C.; Brunberg, E.; Keeling, L.; Piepponen, P. Evidence for a link between tail biting and central monoamine metabolism in pigs (Sus scrofa domestica). Physiol. Behav. 2015, 143, 151-157. [CrossRef] [PubMed]

160. de Haas, E.N.; van der Eijk, J.A.J. Where in the serotonergic system does it go wrong? Unravelling the route by which the serotonergic system affects feather pecking in chickens. Neurosci. Biobehav. Rev. 2018, 95, 170-188. [CrossRef] [PubMed]

161. Kjaer, J.B.; Hjarvard, B.M.; Jensen, K.H.; Hansen-Møller, J.; Naesbye Larsen, O. Effects of haloperidol, a dopamine D2 receptor antagonist, on feather pecking behaviour in laying hens. Appl. Anim. Behav. Sci. 2004, 86, 77-91. [CrossRef]

162. Flisikowski, K.; Schwarzenbacher, H.; Wysocki, M.; Weigend, S.; Preisinger, R.; Kjaer, J.B.; Fries, R. Variation in neighbouring genes of the dopaminergic and serotonergic systems affects feather pecking behaviour of laying hens. Anim. Genet. 2009, 40, 192-199. [CrossRef]

163. Palander, P.A.; Heinonen, M.; Simpura, I.; Edwards, S.A.; Valros, A.E. Jejunal morphology and blood metabolites in tail biting, victim and control pigs. Animal 2013, 7, 1523-1531. [CrossRef]

(C) 2020 by the authors. Licensee MDPI, Basel, Switzerland. This article is an open access article distributed under the terms and conditions of the Creative Commons Attribution (CC BY) license (http://creativecommons.org/licenses/by/4.0/). 